\title{
HELYIDENTITÁS MINT IDENTITÁSORIENTÁCIÓ?
}

\author{
BERZE IVÁN ZSOLT ${ }^{1,2}-$ DÚLL ANDREA ${ }^{2,3}$ \\ ${ }^{1}$ Eötvös Loránd Tudományegyetem, Pszichológiai Doktori Iskola \\ ${ }^{2}$ Eötvös Loránd Tudományegyetem, PPK, Pszichológiai Intézet \\ ${ }^{3}$ BME GTK, Szociológia és Kommunikáció Tanszék \\ Email: berze.ivanzsolt@uni-bge.hu
}

Beérkezett: 2018. február 27. - Elfogadva: 2018. szeptember 14.

\begin{abstract}
Kutatásunkban a helyidentitás elméletét új megközelitésként az identitásorientációkra vonatkozó elképzelésekkel kapcsoltuk össze. Azt feltételeztük, hogy a helyidentitás mérhetô identitásorientációként, tehát értelmezhetô és megbizhatóan mérhetô egyéni különbségeket találunk abban, hogy a helyekkel kiépitett kapcsolat milyen mértékben fontos a személyek számára önmaguk meghatározásában. Feltételeztük továbbá, hogy a vizsgálat keretéül szolgáló eredeti, angol nyelvú kérdôív (AIQ-IV, Cheek, Smith és Tropp, 2002) magyarra fordított változata az általunk használt mintán alkalmas az identitásorientációk mérésére.

Módszer: Feltételezésünk vizsgálatához az AIQ-IV kérdôív magyarra fordított változatát használtuk, amelybe beillesztettük az általunk a szakirodalom alapján megfogalmazott, helyidentitásra vonatkozó tételeket. A kérdốivet három változatban egyetemista mintákon $(n=318,317,281)$ teszteltük, majd az adatok alapján mindhárom esetben faktoranalizist végeztünk. A második változat az elsố verzió eredményei alapján elvégzett módositások révén született. Az elsố változatot a helyekre vonatkozó tételek nélkül is teszteltük, hogy megvizsgáljuk, a helyekre vonatkozó tételek módositották-e az eredeti kérdốv integritását.

Eredmények: A helyekre vonatkozó tételek egy faktorba rendezödtek, a skála statisztikai mutatói megfelelöek, a kitöltốk a helyekre vonatkozó tételeket tudták értelmezni önmaguk meghatározásával kapcsolatban. A kitöltôk által a skálán elért pontszámok normál eloszlást követtek. Ugyanakkor a kérdốv második változatának faktorstruktúrája sem fedte pontosan az eredeti kérdőív skáláit.

Következtetések: A kapott eredmények hozzájárulnak a helyidentitás fogalmának árnyaltabb értelmezéséhez. Tervezzük a második változat eredményei alapján módositott újabb változat nagy elemszámú, más életkorú, nem egyetemista mintán történô felvételét.
\end{abstract}

Kulcsszavak: helyidentitás, (én)identitás, énfogalom, identitásorientáció 


\section{BEVEZETÉS}

A személy és az általa egyéni élményvilágában leképezett és jelentéssel felruházott tér (space), azaz a hely (place, lásd Canter, 1977) közötti kapcsolat egyik speciális formája, amikor a hely összekapcsolódik a személy énfogalmával, identitásának részévé válik. A helyidentitás (Proshansky, Fabian és Kaminoff, 1983; Dúll, 1996) annak Proshansky (1978) általi bevezetése óta a környezetpszichológia központi, ám értelmezését és aspektusait tekintve korántsem teljes kutatói konszenzussal bíró fogalma, amelyet jelen kutatásunk új megközelítésben vizsgál.

\section{Az identitás (énfogalom) aspektusai}

Az identitás fogalmát az azt 1950-es munkájában bevezetố neoanalitikus Erikson (1991) lényegében a személyiségpszichológia kognitív és fenomenológiai irányzataiban megtalálható énfogalom kifejezés szinonimájaként használta (Oyserman, Elmore és Smith, 2012). Minthogy értelmezésében az integrált én érzése a társas világgal való kölcsönhatás nyomán alakul ki, így az identitás alapjában szociális jellegú, és ennek folytán késôbb nagyobb részt a szociálpszichológia által használt fogalommá vált. Az angol nyelvú szakirodalomban sok esetben szinonimaként használt én, énfogalom és identitás fogalmak viszonyának tisztázásában Oyserman és munkatársai (2012) nyújtanak támpontot. ${ }^{1}$ Leírásuk értelmezhetô úgy, hogy az én esetében a folyamat, az énfogalom esetében a struktúra, az identitás esetében pedig az értelmezés, a(z ön)meghatározás és a másokhoz való viszony hangsúlyos.

Az én érzésének megtapasztalása a csecsemó esetében a környezettôl való fizikai különbözôség és a térben történô motorikus cselekvés élményével kezdôdik (Oyserman és mtsai, 2012), majd késôbb a kisgyermek verbálisan is megtanulja megkülönböztetni magát másoktól és a környezeti elemektôl. Az én tehát lényegét tekintve szociofizikai (Dúll, 1996).

Már William James is alapvetô különbséget írt le a spirituális én (az egyénben rejlô belsố szubjektív lény) és a szociális én (a másoktól kapott elismerés, a másokra gyakorolt benyomás) között (Greenwald és Pratkanis, 1984/1992). Egy személy identitását alkotó elemek Miller (1963, idézi Cheek és Briggs, 1982) szerint két általános kategóriába sorolhatók: a társas vagy szociális identitás a személy szociális szerepeit és kapcsolatait, a személyes identitás pedig a személy énjéról alkotott nézeteit, a folytonosság és egyediség érzetét foglalja magában. A legtöbb személy identitása mind szociális, mind személyes aspektusokat tartalmaz, de egyéni különbségek mutatkoznak abban, hogy a személy számára mely aspektusok fontosabbak. A személyes és társas identitás viszonya sok kutatónál megtalálható (Deaux, 1993): egyes elméletalkotóknál nincs lényeges

Oyserman és munkatársai (2012) szerint az én kifejezés magába foglalja a cselekvôt („I”), aki gondolkodik, és gondolatai tárgyát is: önmagát („me”), továbbá azt is, hogy a gondolkodó tudatában is van annak, hogy önmagáról gondolkodni képes. Az énfogalom leírásuk szerint kognitív struktúra, az identitás pedig felfogható úgy, mint annak módja, ahogyan az énfogalom bizonyos aspektusait vagy részeit értelmezzük, és a fogalom esetében fontos a másokhoz való tartozás vagy hasonlóság éppúgy, mint a másoktól való különbözôség. 
tartalmi különbség a kettô között (tartalmuk az egyén kontextushoz történô illeszkedésétôl függ), mások élesen elkülönítik a kettoót (a társas identitás a csoporttagságra, a személyes pedig az egyén személyes kapcsolataira, szerepeire vonatkozik). Deaux szerint a kettô közötti éles különbségtétel önkényes és félrevezetô: ezek alapvetôen kölcsönös kapcsolatban állnak. A személyes identitás, legalábbis részben, a csoporttagság által definiálható, miként a társas identitás is át van itatva személyes jelentéssel. Értelmezésében a társas identitás a személy számára fontos szerepeket és csoporttagság-kategóriákat jelenti, a személyes identitás pedig a személy által önmaga leírására használható jellemzôkre, vonásokra és viselkedésekre vonatkozik.

A személyes-társas dichotómia az énrendszereket, az énfogalmat illetôen a személyiségpszichológiában is megtalálható, így például Greenwald és Pratkanis (1984/1992) négy énfelület vagy énalrendszer elképzelésében (személyes én és kollektív én), Neisser (1988/1992) elméletében (személyes és személyközi én), Fenigstein, Scheier és Buss (1975) nyilvános és személyes éntudatosság fogalmában, Sedikides és Brewer (2001) elképzelésében az énfogalom szerkezetéról (személyes, kapcsolati és kollektív én).

Sampson (1978) szerint vannak személyek, akik énfogalmuk meghatározásában inkább a belsô (önmagukban rejlô) aspektusokat veszik figyelembe, míg mások a külsô aspektusokra helyezik a hangsúlyt. Eszerint egy személy vagy a belsô, vagy a külsô környezete felé irányulhat identitása meghatározásakor, tehát a belsô, és külsô orientáció ugyanazon elméleti dimenzió két végpontja. Sampson kérdốivet is készített a belsô/ külsố orientáció mérésére, de nem közölt adatokat a két skála közötti korrelációs értéket illetôen. Cheek és Briggs (1982) azonban elvégezte a két skála statisztikai értékelését, és csupán gyenge pozitív korrelációt talált, így véleményük szerint a két orientáció két független, bár egymáshoz kapcsolódó dimenziót jelent (Cheek, 1989).

Sampson kérdôíve itemeinek felhasználásával Cheek és Briggs egy új, az identitás ${ }^{2}$ aspektusait mérô kérdőív fejlesztésébe fogott. Az Aspects of Identity Questionnaire (AIQ) kezdetben két orientációt mért: a személyes és társas identitásorientációt. Késôbb (1989) a kérdôív a kollektív identitásorientáció (AIQ-III), míg 2002-ben a kapcsolati identitásorientáció skálájával bôvült (AIQ-IV, Cheek, Smith és Tropp, 2002). A kollektív orientáció esetén a személy identitása meghatározásakor a csoporttagság szerepét és értékét tartja szem elôtt, míg a kapcsolati orientáció esetében a közeli kapcsolatok fontossága a meghatározó. Összehasonlításként Sedikides és Brewer (2001) három (én)reprezentációt írt le (személyes, kapcsolati és kollektív). Elképzelésükben az a reprezentáció, amely azon aspektusokat tartalmazza, ahogyan a személyt mások látják, leginkább a személyes énreprezentáció része.

A személyes és társas identitásorientációval kapcsolatban Cheek és Briggs (1982) e két identitásorientáció és az éntudatosság két fajtája, a személyes és társas éntudatosság (Buss, 1980/2003) kapcsolatának vizsgálatakor együttjárást talált: eredményeik alapján a magas személyes éntudatossággal jellemezhetó személyek identitásuk személyes aspektusait hangsúlyozzák, míg a magas társas éntudatossággal rendelkezó emberek számára énfogalmuk szociális aspektusai különösen fontosak (Cheek, 1989). A személyes és társas identitásorientáció számos kutatás tárgya volt (lásd 
Cheek, 1989), többek között vizsgálták kapcsolatukat az önmonitorozás (Snyder, 1979/2003) konstruktumával.

Az identitás tartalmi (öndefiníciós) aspektusai Berzonsky (1994) elméletében öszszekapcsolódnak az identitás folyamatbeli aspektusaival. Szociálkognitív modelljében három identitás-folyamatorientációt, illetve identitásstílust írt le: az információorientált, a normaorientált és a diffúz/elkerülô identitásstílust, amelyeket összekapcsolt a Marcia (1966) által leírt négy identitásállapottal is. Eredményei szerint a személyes jellemzőkön és értékeken nyugvó öndefiníció az információorientált, a kollektív jellegú (csoportközi összehasonlításon alapuló) a normaorientált, a társas alapú (interperszonális összehasonlításon alapuló) pedig a diffúz/elkerülô identitásstílushoz kapcsolható (Berzonsky, 1994).

\section{Identitásaspektusok és hely}

A társas identitás elmélet (Tajfel, 1982) az identitás szociális jellegére koncentrál. Az elmélet értelmében az identitás kialakítása csoportok közötti összehasonlításon alapul és azon csoportok minôségének függvénye, amelyekhez az egyén tartozik. Twigger-Ross, Bonaiuto és Breakwell (2003) környezetpszichológiai elmélete szerint a fizikai környezet szerepét figyelmen kívül hagyó társas identitás elmélet könnyen átalakítható úgy, hogy tartalmazza a hely aspektusát: az emberek egy hely esetében ugyanúgy emelhetik annak státuszát és észlelhetik inkább annak pozitív tulajdonságait a pozitív identitás és az önértékelés növelése érdekében, mint saját csoportok esetében.

Az önkategorizációs elmélet (Turner és Reynolds, 2012) már a személyes nézópontot is figyelembe veszi: az identitás természete és szociális jellege, azaz az önkategorizáció szintje (csoport- vagy személyközi) eszerint kontextuális hatásoktól függ. Az elméletben a kontextuális hatások szociális jellegúek, a környezeti kontextus a jelen lévố szociális ágensekre vonatkozik. Bernardo és Palma-Oliveira (2013) ugyanakkor rámutattak, hogy az önkategorizációs elmélet a helyekkel való kapcsolatot illetôen is alkalmazható.

Breakwell (1986) identitásfolyamat-elméletében nem tesz különbséget a személyes és szociális identitás között. Az identitás folyamataiban szerinte négy elv érvényesül: a megkülönböztethetôség (a személyek önmaguk másoktól való elkülönítésének és egyediségének vágya), a folytonosság (az énfogalom folytonosságának megórzése), az önértékelés (önmagunknak vagy a saját csoportnak pozitív értékelése, a személyes és szociális értékesség érzése), majd késôbb bekerült negyedik elvként az énhatékonyság (a szituációnak való megfelelés képességének hite). Breakwell szerint - szimbolikus jellegük, személyes és kollektív emlékezetben betöltött szerepük által - a helyek nagyon fontos identitásforrások. A helyek a megkülönböztethetôség, a folytonosság és az önértékelés elvének érvényesülésében is szerepet játszanak (Twigger-Ross és Uzzell, 1996), de az énhatékonysághoz is kapcsolódnak: bizonyos célok eléréséhez egy adott hely lehet az egyén számára a legmegfelelőbb, lásd helyfüggôség (Stokols és Shumaker, 1981). 


\section{Helyidentitás}

A környezetpszichológusok szerint az identitás alakulásában nagyobb hangsúllyal kell figyelembe venni a fizikai környezet hatását. A kérdés, „kik vagyunk”, gyakran közvetlenül kapcsolódik ahhoz a kérdéshez, „hol vagyunk” (Dixon és Durrheim, 2000).

A hely és az identitás kétféle módon (Twigger-Ross és Uzzell, 1996) kapcsolódhat: részben a helyazonosulás mechanizmusában, ami a hely azon jellemzőire vonatkozik, amelyek megkülönböztetố identitást adnak a helynek a használói gondolkodásában („londoni vagyok”) - ebben az értelemben a környezet helyvonatkozású társas kategóriának tekinthetố; a másik hely-identitás kapcsolat a helyidentitás. A helyazonosulás esetén a hangsúly a helyen van, a helyidentitás esetében pedig az identitás pszichológiai konstruktumán és annak a társas identitással való kapcsolatán (Uzzell, Pol és Badenas, 2002).

A helyidentitás elmélet (Proshansky, 1978) szerint a helyekkel való interakció az aktuálisan lezajló észlelési és/vagy kognitív folyamatokban alakul ki. A fejlődés során önmagunkat nemcsak a fontos mások, hanem a fizikai környezet viszonylatában is meghatározzuk (Proshansky, Fabian és Kaminoff, 1983). A helyidentitás Proshansky szerint nem egyszerúen érzelmi kötôdés egy helyhez vagy az ahhoz tartozás érzése, hanem - a társas identitáshoz hasonlóan - az identitás önálló alstruktúrája, amely a személy fizikai világgal kapcsolatos szocializációját tartalmazza (Twigger-Ross és Uzzell, 1996). Proshansky szerint a helyidentitás hangsúlyozza a személyes identitásokat, érthetôvé teszi a tetteket és tevékenységeket, kifejez tetszést és preferenciákat, és közvetíti a környezet megváltoztatását célzó törekvéseket (Dixon és Durrheim, 2000; Dúll, 1996) - tehát, miként az énfogalom, állandóan fejlôdô dinamikus jelenség (TwiggerRoss és Uzzell, 1996).

\section{A helyidentitás helye az identitások rendszerében}

Proshansky szerint a helyidentitás kapcsolatban van a társas identitással, ugyanakkor nem tisztázza a köztük lévô viszonyt. Szétválasztásuk viszont ellentmondana a környezetpszichológia tranzakcionális szemléletének (Dúll, 2009). Twigger-Ross és Uzzell (1996) szerint az identitás minden aspektusa rendelkezik több-kevesebb hellyel kapcsolatos vonatkozással. Bernardo és Palma-Oliveira (2003) szerint a helyidentitás a társas identitás alstruktúrájának tekinthetô. Knez és Eliasson (2017) értelmezésében sem a személyes, sem a kollektív (társas) identitás nem mentes a helyektốl, a helyidentitás lehet személyes vagy kollektív jellegú, mindkét esetben érzelmi és kognitív összetevôkkel. Twigger-Ross, Bonaiuto és Breakwell (2003) hasonlóképpen úgy gondolják, hogy a helyekkel történô azonosulás nyomán születố helyidentitások az énnek mind a személyes, mind a társas aspektusait magukban foglalják. Hinds és Sparks (2008) szerint az emberek kialakíthatnak környezeti identitást úgy, hogy az erôs társas összetevôvel bír, de úgy is, hogy a környezeti identitásuknak csekély társas kapcsolódása van. Hauge (2007) egy integratív modellt kínál az egyes ellentmondó elméletek helyett, és felveti: ne úgy tekintsünk a helyidentitásra, mint az identitásrendszer egy vertikális elhelyezkedésú kategóriájára (mint a nem vagy a társadalmi osztály), hanem mint egy horizontális dimenzióra, amely az identitás vertikálisan elhelyezkedô dimenzióin áthaladva helyezkedik el. 


\section{A helyidentitás kutatása}

A helyidentitással kapcsolatos elképzelések és kutatások - sokszor egymással átfedésben - érintették annak viszonyát az egyéb, helyekkel kialakított kapcsolatokat célzó fogalmakkal, definícióját (pl. Twigger-Ross és Uzzell, 1996; Korpela, 1989; Dixon és Durrheim, 2000), ezzel együtt akár szúkebb és speciálisabb fogalmak meghatározását (pl. Lalli, 1992: városi identitás; Feldman, 1990: letelepedés identitás; Félonneau, 2004: topológiai identitás), összetevôit (pl. Lalli, 1992; Droseltis és Vignoles, 2010), előrejelzôit (pl. Rollero és De Piccoli, 2010; Hernández, Hidalgo, Salazar-Laplace és Hess, 2007; Knez, 2014; Main és Sandoval, 2015) és mindezekkel együtt funkcióit.

Az emberek helyekkel kialakított kapcsolatára számos elmélet és fogalom született a helyidentitás mellett többek között a helyérzék (Hummon, 1992; Jorgensen és Stedman, 2001), a helykötôdés és a helyfüggôség (Stokols és Shumaker, 1981) -, ám ezek a fogalmak sok esetben elég lazán definiáltak, és kapcsolatuk tisztázatlan (Manzo, 2003; Hernández, Hidalgo, Salazar-Laplace és Hess, 2007; Rollero és De Piccoli, 2010). Ezek közül a helykötôdésnek, az egyének és a számukra fontos helyek közötti érzelmi köteléket jellemzô fogalomnak (Dúll, 2009) van a legszélesebb irodalma. A helykötôdés és a helyidentitás fogalmak kapcsolatát tekintve szintén sokféle elképzelés született, amelyek közül vizsgálatunk Proshansky eredeti definícióját alapul véve abba a vonulatba ${ }^{3}$ illeszkedik, amely szerint a helykötôdés a helyidentitás része, illetve elôzménye (pl. Korpela, 1989; Lalli, 1992; Droseltis és Vignoles, 2010; továbbá Hernández és mtsai, 2007; Casakin, Hernández és Ruiz, 2015; Rollero és De Piccoli, 2010; Knez, 2014): a helyek identitásban betöltött szerepe esetében a helyekkel kialakított érzelmi kapcsolatot fontos aspektusnak tekintjük.

A helyidentitást célzó kutatások legnagyobbrészt azt célzottan elóhívó helyzetben, konkrét helyek, például egy bizonyos város(rész) és környezete vagy egy adott természeti hely ott élook vagy oda gyakran látogatók általi megítélésével, illetve a vizsgálati személyek által megnevezhetố kedvenc helyek kapcsán vizsgálták a fogalmat vagy annak valamely fent említett aspektusát. Kutatásunkban igyekszünk a helyidentitást általánosságban, konkrét helyeket nem megnevezve, a személyiség szintjén, az identitás/ énfogalom más aspektusaival együtt vizsgálni.

\section{A KUTATÁS CÉLKITÜZÉSEI}

Jelen korrelációs stratégiát alkalmazó, keresztmetszeti kutatásunk új megközelítésben, identitásorientációként célozta vizsgálni a helyidentitást. Kutatásunk egy hosszabb vizsgálatsorozat elsô lépése. Jelen vizsgálatban azt feltételeztük, hogy a helyidentitás mérhetô identitásorientációként, azaz értelmezhetô és megbízhatóan mérhetô is egyéni különbség abban, hogy az egyes személyek a számukra jelentôs helyeket és azokhoz

Egyéb elképzelések: (1) a két fogalom ugyanaz a konstruktum (Brown és Werner, 1985); (2) a helyidentitás a helykötôdés része (pl. Williams és Roggenbuck, 1989; Kyle, Graefe és Manning, 2005; Hinds és Sparks, 2008); (3) mindkettố egy magasabb rendú fogalom része (Hummon, 1992; Jorgensen és Stedman, 2001). 
füződô kapcsolatukat mennyire tartják fontosnak önmaguk meghatározásában. Ezt egy már létezô, az énfogalom aspektusainak mérésére készült kérdôív segítségével vizsgáltuk, ezen elsô lépésben kényelmi mintavételt alkalmazva egyetemista mintán. A kutatás kiegészítố célja az volt, hogy megvizsgáljuk, hogy a helyidentitás vizsgálatának keretéül szolgáló angol nyelvú kérdôív lefordítása után alkalmas-e mintánkon az identitásorientációk mérésére, hiszen a különbözô orientációk közötti kapcsolatok vizsgálata csak azok megfelelő mérése esetén lehetséges majd. Utóbbi kérdést több lépésben, a kérdôív módosításai során vizsgáltuk. A kutatás etikai engedélyét az ELTE PPK Kutatásetikai Bizottsága állította ki 2016/129-es iktatószámmal.

\section{Eljárás}

A kérdôívre vonatkozó dokumentációt a kérdôív különbözô változatai szerint strukturáljuk.

\section{A kérdốiv elsố változata}

Vizsgálatunkban a szakirodalmi áttekintésben említett Aspects of Identity Questionnaire kérdốiv negyedik változatát (AIQ-IV, Cheek és mtsai, 2002) használtuk fel, amelyet saját tételekkel egészítettünk ki. A kérdôív változatai közül a legújabb mellett döntöttünk, mivel az jó pszichometriai jellemzókkel rendelkezik: érvényes, a skálák konvergens és diszkrimináns validitása is megfelelố (Cheek és mtsai, 2002). A legújabb és legtöbb itemmel rendelkezô változat választásában szerepet játszott, hogy az új kérdéseket jobban el tudjuk osztani az eredeti kérdések között, továbbá, hogy feltáró vizsgálatot végezzünk annak tekintetében, a kérdôív minden faktorát megtaláljuk-e a saját mintánkon végzett számításokkal. A kérdốiv eredetileg 45 kérdést tartalmaz, mind a kérdốiv, mind a skálái és az azokhoz tartozó tételek leírása angol nyelven szabadon hozzáférhetô (https://www.midss.org/sites/default/files/aiq.pdf - utolsó letöltés: 2018. 02. 25.). A kérdőív kitöltésekor a válaszadó ötfokú Likert-skálán döntheti el, hogy az adott tételt mennyire érzi fontosnak önmaga meghatározásában. Az angol nyelvú kérdôív négy skálát (négy identitásorientációt) mér, azaz mennyire fontosak a személy számára önmaga meghatározásában a

1. személyes aspektusok (10 kérdés): belsô jellemzôk (értékek, gondolatok, érzések, célok), énjérôl alkotott nézetei, folytonosság és egyediség érzete;

2. kapcsolati aspektusok (10 kérdés): közeli kapcsolatok (barátság, párkapcsolat) minôsége és a személy ezekben betöltött szerepe;

3. társas aspektusok (7 kérdés): szociális szerepek, ahogyan ôt mások látják és ahogyan gondolkodnak róla;

4. kollektív aspektusok (8 kérdés): a (nem választott) csoporttagság (család, etnikum, vallás/felekezet, nemzet, anyanyelv) szerepe és értéke.

A kérdôív tartalmaz továbbá 10, a fenti négy skálába nem tartozó tételt is. A skálák tartalmát a 9. táblázatban foglaltuk össze.

A vizsgálatban felhasznált magyar nyelvú és a helyidentitásra vonatkozó tételekkel kiegészített kérdôív elsố változatának kidolgozása az alábbi lépésekben történt: (1) az 
angol nyelvú tételek nyers fordítása magyar nyelvre, (2) a szociokulturális sajátosságok figyelembevételével finomítás ${ }^{4}$ a tételek magyar nyelvú megfogalmazásában, (3) a tételek érthetôségének ellenôrzése külsô megítélôkkel, (4) a tételek visszafordítása angol nyelvre, (5) a helyidentitásra vonatkozó tételek kialakítása és (6) beillesztése a skála eredeti tételei közé.

A helyidentitással kapcsolatos tételek kialakítása az alapján történt, hogy (1) a tételek megfeleljenek a szakirodalmi megfontolásoknak, és (2) megfelelôen differenciáljanak a személyek esetében. Ez utóbbi megfontolás miatt nem kerültek a tételek közé olyanok, amelyek konkrét helyekre utalnak: például nem szerepel a tételek között az otthon, ami nagyon erôs helyidentitáskeltô hely, így esetében könnyen várhatunk nagyon hasonló válaszokat a teljes mintát tekintve. (3) Fontos volt továbbá, hogy az új tételek a kérdőív eredeti tételének stílusában kerüljenek megfogalmazásra.

Kilenc darab hellyel kapcsolatos tételt fogalmaztunk meg. Az egyes tételek a helyidentitás következô aspektusaira vonatkoznak: (1) a helykötôdésre (vö. Korpela, 1989; Dúll, 2002), amelyet a helyidentitás szükséges bázisának tekintünk („Kötốdésem egy-egy természeti vagy épített környezeti helyhez.”), (2) a hely személyre gyakorolt hatására, (3) nem specifikus aspektusra (tranzakcionális jellegú általános tétel), (4) a környezettel kapcsolatos érzésekre és kötődésre (vö. Proshansky és mtsai, 1983; Dixon és Durrheim, 2000), (5) a környezettel kapcsolatos jelentésre és (6) a környezettel kapcsolatos emlékekre (vö. Dúll, 1996), (7) (8) az énfogalomhoz kapcsolódásra (vö. Jorgensen és Stedman, 2001; Droseltis és Vignoles, 2010), (9) a környezeti preferenciára (vö. Dúll, 1996).

A helyekkel való kapcsolat fontosságát mérô tételeket az eredeti kérdések közé elszórva illesztettük be (lásd alább 9. táblázat). Bár ez felveti azt a módszertani problémát, hogy így sérülhetett az eredeti kérdôív integritása, a vizsgálat célja alapvetôen nem az AIQ-IV kérdôív magyar változatának elkészítése, hanem a helyek identitásban betöltött szerepében kimutatható egyéni különbségek vizsgálata volt. Emellett el kívántuk kerülni, hogy a közvetlenül egymás alá kerülô, azonos konstruktumot mérô tételeket a válaszadók hasonlóbbnak lássák és könnyen adjanak rájuk ugyanolyan választ.

Külön említést érdemel az eredeti 13. tétel: „Helyek, ahol élek vagy ahol felnôttem." A tétel a kollektív skálához tartozik, a helyek kifejezés ebben az esetben az ott jelen lévô szociális ágenseket, a jelen lévô csoportokhoz való tartozást célozza. A tételt a helyidentitással kapcsolatos kérdések beillesztése után sem töröltük, a megfogalmazásán sem változtattunk, hiszen ez a tétel diszkriminációs validitást biztosító szerepú az új tételeket tekintve.

A kérdôív így elkészült változatát a Budapesti Gazdasági Egyetem (BGE) Kereskedelmi és Vendéglátóipari Kara, valamint az Eszterházy Károly Egyetem hallgatói töltötték ki papír-ceruza formátumban, az egyetemi órák elsô vagy utolsó perceiben a

4 Például a 35. tétel („Connecting on an intimate level with another person”) csupán közeli, meghitt viszonyt jelöl-e; 4. tétel („Being a part of the many generations of my family”), ahol nem a családi kapcsolatok fontosságát, hanem a családhoz mint közösséghez tartozást volt fontos hangsúlyozni; 10. tétel („My religion”), ahol szintén a kollektív aspektus hangsúlyozása volt a cél a belsôleg megélt vallás vagy hit helyett. Ugyanakkor alapvetô cél volt az is, hogy az elsố változatban a fenti elvek figyelembevétele mellett megôrizzük az eredeti kérdôív tételeit, azaz a fordítás átértelmezést ne, legfeljebb pontosítást tartalmazzon. 
vizsgálatról szóló tájékoztató részükre történô felolvasása után. A tájékoztatóban szerepelt: a kérdốiv kitöltésével elismerik, hogy a kutatásban való részvétel körülményeirôl elegendô információt kaptak, az elhangzottakkal egyetértenek, és a részvételt vállalják. Erről a kérdôív elsô oldalán minden hallgató nyilatkozatot tehetett. A kitöltés önkéntes (aki nem kívánta kitölteni a kérdôívet, visszaadhatta az üres úrlapot) és anonim volt, a kitöltést vállaló hallgatók ösztönzô jutalomban nem részesültek. A kitöltött ívek a digitalizálást követôen haladéktalanul megsemmisítésre kerültek, a digitális adatbázist biztonságos, csak általunk hozzáférhetô számítógépen tároltuk. 318 db kitöltött kérdőívet kaptunk vissza, ezek közül 310 db volt használható, 7 db kérdôív adatait hiányos kitöltés miatt, $1 \mathrm{db}$ kérdôív adatait a nyilatkozat elmaradása miatt nem tudtuk felhasználni. A 310 kitöltôből 223 nô, 87 férfi, életkoruk átlaga: 20,76 év, szórása: 2,28, alsó életkor: 18 év, felsô életkor: 40 év volt.

A kérdőív kitöltésével kapott adatokon az SPSS program 15.0 verziójának segítségével itemanalízist, megbízhatósági számítást, majd azok arra való alkalmasságának tesztelése után faktoranalízist végeztünk (lásd Eredmények). A feltáró analízisben principal axis factoring becslési módszert használtunk, az 1-nél nagyobb sajátértékú (azaz egy változónál több információt hordozó) faktorokat vizsgáltuk, legfeljebb 25 iterációt engedtünk meg, a faktorsúlyok közül csak a jelentést hordozó 0,35 felettieket tartottuk meg. Mivel a helyidentitás identitásstruktúrában elfoglalt helye vitatott, továbbá célunk elsôsorban a helyekre vonatkozó tételek viselkedésének vizsgálata volt, ugyanakkor a szakirodalom alapján az egyes identitásaspektusok összefüggenek, a faktorok forgatásához a faktorstruktúra és stabilitásának teljesebb elemzése érdekében a faktorok függetlenségét megôrzô derékszögû (Varimax) és azok korrelációját megengedő ferde (Promax) forgatást is alkalmaztunk. Az általunk beillesztett, helyidentitásra vonatkozó tételeken a faktoranalízis eredményének függvényében külön megbízhatósági számítást és itemanalízist, valamint eloszlásvizsgálatot készítettünk.

\section{A kérdôiv második változata}

A kérdôív elsố változatának eredményein elvégzett feltáró faktoranalízis alapján szükségesnek találtuk néhány tétel átfogalmazását és így egy második változat elkészítését. Míg az elsô változat elkészítésekor a szociokulturális tényezôk figyelembevétele mellett alapvetôen igyekeztünk az eredeti tartalomhoz és megfogalmazáshoz ragaszkodni, a tételek módosításakor a jobb értelmezhetôség és a skálához tartozás érdekében egy-két markánsabb, de a tétel alapvetô jellegét megôrzô átfogalmazásra is sor került.

20 tétel szövegezésében történt módosítás. A módosítás lehetett szavak felcserélése ${ }^{5}$ vagy átfogalmazás ${ }^{6}$. Az eredmények alapján a kollektív orientáció skálája esetében ko-

5 Pl. az 5. item „Álmaim és képzeletem” új szövegezése „Képzeletem és álmaim” lett, mivel az eredeti megfogalmazással a tétel egy külön, elérendô célok címkével jellemezhetô faktorba került.

6 Pl. a 19. tétel „Gesztusom, egyéni stílusom, másokra tett benyomásom” átfogalmazása jobban hangsúlyozza a társas jelleget: „Másokra tett benyomásom gesztusaim, kifejezésmódom által”. 
molyabb átfogalmazásokra is sor került a hazai szociokulturális jellemzôknek megfelelốen. ${ }^{7}$ Kitöltối visszajelzés alapján is módosítottunk tételt. ${ }^{8}$

A helyekre vonatkozó tételekból is módosítottunk kettőt: az egyiket azért, hogy ne egy elképzelt helyre célozzon a tétel („,...ott igazán önmagam lehetek” helyett „...ott igazán önmagam vagyok”), az utolsót pedig kicseréltük, hogy a személyiséghez kapcsolódást, így a helyidentitást erôsebben hangsúlyozza („...ami tükrözi a személyiségemet”). A 14. (az eredeti angol nyelvú kérdôívben 13.) tételt is átfogalmaztuk a „most” szó beírásával („Helyek, ahol most élek vagy ahol felnôttem”), hogy a kollektív jelleget erôsítsük és a származás jelleget csökkentsük. Az átfogalmazással továbbá kísérletet tettünk arra, hogy megvizsgáljuk, a tétel így sem tartozik-e majd a helyidentitást célzó skálába.

A kérdốiv így elkészült változatát a BGE Kereskedelmi és Vendéglátóipari Karának, Külkereskedelmi Karának, valamint a Pénzügyi és Számviteli Karának hallgatói töltötték ki. A kérdôívek kitöltése az elsô változattal egyezô módon és feltételek mellett papír-ceruza formátumban történt. 317 db kitöltött kérdőívból 4 kitöltése hiányos volt, így 313 db-ot használtunk fel. A 313 kitöltôból 182 nô, 131 férfi, életkoruk átlaga: 21,25 év, szórása: 1,84, alsó életkor: 18 év, felsố életkor: 31 év volt. A kitöltook kiválasztásánál ügyeltünk arra, hogy a kérdôív ezen változatát ne az elsố változatot ismerô hallgatók töltsék ki.

A kérdőív ezen változatának kitöltésével kapott adatokon az SPSS program 15.0 verziójának segítségével az elsố változatnál leírt statisztikai számításokat (a helyidentitás-tételek esetében külön is), valamint az ott leírt módon feltáró faktoranalízist végeztünk. Ezen, mint látni fogjuk, az eredeti kérdôívhez közelebb álló faktorstruktúrájú változat esetében a faktorstruktúra stabilitásának, illeszkedésének ellenôrzéséhez az MPlus program 8-as verziójával strukturális egyenlet modellezésen (SEM) alapuló konfirmatív faktorelemzést (CFA) készítettünk ${ }^{9}$ (lásd Eredmények).

\section{A kérdôiv helyekre vonatkozó tételek nélküli $(H N)$ változata}

Továbbra is érvényesnek tekintve annak szakmai indoklását, hogy a helyidentitásra vonatkozó tételek miért elszórva kerültek be a magyarra fordított eredeti tételek közé, elkészítettük a kérdôív helyidentitást célzó tételek nélküli, tehát csak az eredeti, de magyarra fordított, az elsô változatban szereplô tételeket tartalmazó változatát. Célunk az volt, hogy felmérjük, mennyiben sértette végül a helyidentitással kapcsolatos tételek beillesztése az eredeti kérdôív integritását: a magyarra fordított tételek kitöltése alapján elóálló faktorstruktúra mennyiben egyezik vagy tér el (1) az eredeti kérdôívétôl annak négy faktorát tekintve, illetve (2) a helyidentitással kapcsolatos tételeket is tartalmazó elsố változat faktorstruktúrájától.

7 Pl. a 33. tétel, „A hazám büszke polgárának lenni” és a 44. tétel „Elkötelezettségem politikai téren, illetve politikai tevékenységem” szövegezését módosítottuk, előbbi „Nemzeti hovatartozásom”, utóbbi „Politikai nézeteim és állásfoglalásom” lett, mindkettô jobban hangsúlyozza a kollektív jelleget.

8 Pl. a 20. tétel („Ahogyan a félelmeimet és szorongásaimat kezelem”) esetében néhány kitöltô jelezte, hogy a „félelmek és szorongások” említése miatt a tétel nehezebben általánosítható mindenkire, így a tételt általánosabb problémamegoldásra és megküzdô képességre vonatkozóan fogalmaztuk át.

9 Köszönet illeti Urbán Róbertet (ELTE Pszichológiai Intézet) a SEM-elemzés kivitelezésében nyújtott segítségéért. 
Ezt a változatot a BGE Kereskedelmi és Vendéglátóipari Karának hallgatói töltötték ki. A kérdôívek kitöltése az elôzô változatokkal egyezô módon és feltételek mellett papír-ceruza formátumban történt. $281 \mathrm{db}$ kitöltött kérdőívból 279 db-ot használhattunk, 2 kérdôív kitöltése hiányos volt. A 279 kitöltôből 189 nô, 90 férfi, életkoruk átlaga: 20,36 év, szórása: 2,66, alsó életkor: 18 év, felsố életkor: 55 év volt. A kitöltôk kiválasztásánál ügyeltünk arra, hogy ezt a változatot az elôzó változatokat nem ismerô hallgatók töltsék ki.

A kérdôív ezen változatának kitöltésével kapott adatokon az SPSS program 15.0 verziójának segítségével az elsố változatnál leírt statisztikai számításokat, valamint az ott leírt módon feltáró faktoranalízist végeztünk. Ennél a változatnál a faktoranalízist további értelmezéshez és konfirmatív célzattal mindkét rotációt alkalmazva elvégeztük úgy is, hogy az elemzés során megadtuk a várt faktorok, azaz az eredeti angol nyelvú kérdôív skáláinak számát (lásd Eredmények).

\section{EREDMÉNYEK}

\section{Statisztikai mutatók}

A kérdőív egyetemista mintán felvett három változatának statisztikai mutatói alapján mindhárom változat (1) megbízható (Cronbach- $\alpha$ értéke: I: 0,900; II: 0,888; HN: 0,888); (2) látszatérvényességük (face validity) az elsô változat lefordított tételeinek külsô megítélői és a kitöltôk visszajelzései alapján megfelelô, továbbá egy már létezô, érvényes kérdôív tételein alapulnak, az elsô két változatban az új tételek pedig a vonatkozó szakirodalom alapján kerültek kialakításra; (3) itemszerkezetük megfelelô: a Cronbach- $\alpha$ értéke csak egy vagy két tétel (I: 6. és 34.; II: 38.; HN: 38.) kiemelése esetén volna egy-két ezreddel magasabb.

A kérdôív mindhárom változatának kitöltésével nyert adatok alkalmasak faktoranalízisre: (1) KMO értéke: I: 0,832; II: 0,831; HN: 0,838; (2) Bartlett-teszt szignifikáns: $\mathrm{p}<0,01$; (3) Anti-image mátrix: minden érték $0,5<$. Az elemszám ( $\mathrm{n}=310 ; 313$; 279) mindhárom változat esetében az általunk végzett feltáró jellegú vizsgálathoz megfelelőnek tekinthetô (Guilford (1954) szerint 200, Cattell (1978) szerint 250 a faktoranalízishez szükséges minimális elemszám, Comrey és Lee (1992) a 300-as elemszámot már jónak tekinti, Gorsuch (1983) szerint a változószám ötszöröse a megfelelố elemszám - idézi óket MacCallum, Widaman, Zhang és Hong, 1999).

\section{A helyekre vonatkozó tételek}

A faktoranalízis során a helyidentitást célzó 9 új tétel mindegyike egy faktorba került mindkét változatban. Ennek nyomán külön skálaként kezelhetôk, amelynek megbízhatósága magas (Cronbach- $\alpha=0,874$, ill. 0,909). Az itemanalízis egyik itemnél sem jelez problémát (a Cronbach- $\alpha$ értéke bármely item kiemelése esetén alacsonyabb volna, mint a jelenlegi érték). Az itemek közötti korrelációk mindegyike szignifikáns $(\mathrm{p}<0,01)$, a korrelációs együtthatók értéke 0,220 és 0,772, illetve 0,339 és 0,752 között 
mozog. A skálán elért összpontszámok átlaga 30,28, illetve 28,91, szórása 6,462, illetve 7,284, eloszlásuk normál eloszlású, a kitöltôk között az egészen alacsonytól (11 pont; illetve a legalacsonyabb érték: 9 pont) a legmagasabb értékig (45 pont) születtek összpontszámok. A második változatban a legalacsonyabb értéket mindössze egy személy érte el, ez a teljes minta csupán 0,003\%-át jelenti.

A második változatban a helyidentitás-tételek skálájának Cronbach- $\alpha$ értéke a két, helyidentitást célzó tétel (48. és 53.) módosítása után magasabb lett, továbbá a módosított tételek többi helyidentitásra vonatkozó tétellel számított korrelációs értékei szintén növekedtek, ami igazolja módosításuk helytállóságát.

\section{Faktorstruktúrák}

A feltáró faktoranalízis során Varimax és Promax rotációt is alkalmaztunk mindhárom változat (I, II és HN) esetében. Az így kapott 1-nél nagyobb sajátértékú faktorok (I: 14; II: 15; HN: 12) közül a könyökszabályt (Scree-tesztet) alkalmazva maximalizáltuk az elemzésben értelmezett faktorok számát: I: 6; II: 6/7; HN: 5.

Mindhárom változatra igaz, hogy a ferde Promax forgatás eredményei a faktorok tartalmát tekintve lényegesen nem térnek el a Varimax rotáció eredményeitôl (az egyes faktorokat tekintve nincs eltérés vagy faktoronként csupán egy-egy tételben tér el a két tartalmi struktúra - a faktortöltések különböznek), az elemzésben értelmezett faktorok közötti korreláció nem magas: a korrelációs együtthatók értéke I: -0,175 és 0,433; II: -0,090 és 0,399; HN: -0,017 és 0,578 közötti. Az értelmezésben elsôsorban a Promax rotáció (mintázat mátrixának) eredményeit vettük figyelembe.

A második változat Promax ferde rotációval létrejött faktorstruktúrája a strukturális egyenlet modellezésen alapuló konfirmatív faktoranalízis eredményei alapján stabilnak és jó illeszkedésûnek mondható $\left(\chi^{2}=735,54\right.$, df $=450$, RMSEA = 0,045, CFI = 0,908, SRMR = 0,063). Bár a Varimax forgatás nem engedi a faktorok közötti korrelációt, a ferde forgatáshoz hasonló, de egy-egy ponton az eredeti struktúrát jobban közelítô, és a Promax rotáció struktúra mátrixával összhangban lévô eredménye miatt a Varimax forgatással létrejött faktorstruktúra illeszkedését is megvizsgáltuk a SEM módszerrel, és az eredmények alapján ez is (bár a Promax-struktúrához képest kevésbé) stabilnak mondható $\left(\chi^{2}=958,14, \mathrm{df}=580, \mathrm{RMSEA}=0,046, \mathrm{CFI}=0,890, \mathrm{SRMR}=0,065\right)$.

A magyarázott variancia értékei mindhárom változat esetében alacsonyak: az 1-nél nagyobb sajátértékú faktorok esetén I: 48,761\%, II: 49,364\%, illetve HN: 47,766\%; a maximalizált számú faktorok esetén I: 37,271\%, II: 37,7\%/39,685\%, illetve HN: 36,293\%; a HN-változat konfirmatív 4 faktoros megoldása esetén 32,472\%.

A létrejött faktorstruktúrákat az elsố változat esetében az 1. és 2., a második esetében a 3., 4. és 5., a HN-változat esetében pedig a 6., 7. és 8. táblázatban foglaltuk össze.

Az elsô változat feltáró elemzéssel született faktorstruktúráiban a faktorok tartalma a derékszögú és ferde rotáció esetében szinte tökéletesen megegyezik. 
1. táblázat. A kérdôív elsố változatának adatain végzett feltáró faktoranalízis eredménye az elemzésben értelmezett faktorokat tekintve

\begin{tabular}{l|c|c|c|c|c|c|}
\hline \multicolumn{7}{|c|}{ Varimax forgatással } \\
\hline Tételek* & \multicolumn{7}{|c|}{ Faktorok } \\
\hline & F1 & F2 & F3 & F4 & F5 & F6 \\
\hline H30 &, 845 & & & & & \\
\hline H35 &, 830 & & & & & \\
\hline H21 &, 677 & & & & & \\
\hline H18 &, 652 & & & & & \\
\hline H45 &, 617 & & & & & \\
\hline H8 &, 611 & & & & & \\
\hline H40 &, 587 & & & & & \\
\hline H48 &, 456 & & & & & \\
\hline H53 &, 428 & & & & & \\
\hline K49 & &, 690 & & & & \\
\hline K51 & &, 681 & & & & \\
\hline K43 & &, 663 & & & & \\
\hline K36 & &, 643 & & & & \\
\hline K29 & &, 594 & & & & \\
\hline K39 & &, 563 & & & & \\
\hline K25 & &, 494 & & & & \\
\hline S12 & &, 423 & & & & \\
\hline C27 & &, 418 & & & & \\
\hline T13 & & &, 836 & & & \\
\hline T6 & & &, 714 & & & \\
\hline T16 & & &, 622 & & & \\
\hline T3 & & &, 575 & & & \\
\hline S31 & & & &, 619 & & \\
\hline T19 & & & &, 576 & & \\
\hline S24 & & & &, 552 & & \\
\hline S37 & & & &, 426 & & \\
\hline S20 & & & &, 369 & & \\
\hline T23 & & & &, 358 & & \\
\hline S28 & & & & & & \\
\hline S9 & & & & &, 629 & \\
\hline S5 & & & & &, 582 & \\
\hline S15 & & & &, 373 &, 495 & \\
\hline C4 & & & & & &, 692 \\
\hline C14 & & & & & &, 574 \\
\hline
\end{tabular}

\begin{tabular}{|c|c|c|c|c|c|c|}
\hline \multicolumn{7}{|c|}{ Promax forgatással } \\
\hline \multirow[t]{2}{*}{ Tételek* } & \multicolumn{6}{|c|}{ Faktorok } \\
\hline & F1 & $\mathrm{F} 2$ & F3 & $\mathrm{F} 4$ & F5 & F6 \\
\hline $\mathrm{H} 30$ & ,890 & & & & & \\
\hline H35 & ,869 & & & & & \\
\hline $\mathrm{H} 21$ & ,693 & & & & & \\
\hline H18 & ,669 & & & & & \\
\hline $\mathrm{H} 8$ & ,639 & & & & & \\
\hline $\mathrm{H} 45$ & ,635 & & & & & \\
\hline $\mathrm{H} 40$ &, 550 & & & & & \\
\hline $\mathrm{H} 48$ & ,357 & & & & & \\
\hline $\mathrm{H} 53$ & ,352 & & & & & \\
\hline K49 & &, 771 & & & & \\
\hline K43 & &, 742 & & & & \\
\hline K36 & & ,668 & & & & \\
\hline K29 & & ,633 & & & & \\
\hline K51 & & ,632 & & & & \\
\hline K39 & & 600 & & & & \\
\hline K25 & &, 471 & & & & \\
\hline $\mathrm{S} 12$ & & ,411 & & & & \\
\hline $\mathrm{C} 27$ & &, 380 & & & & \\
\hline $\mathrm{T} 13$ & & & 843 & & & \\
\hline $\mathrm{T} 6$ & & & ,763 & & & \\
\hline T3 & & &, 541 & & & \\
\hline T16 & & & , 496 & & & \\
\hline T19 & & & & ,687 & & \\
\hline S31 & & & &, 657 & & \\
\hline S24 & & & & ,654 & & \\
\hline $\mathrm{T} 23$ & & & &, 380 & & \\
\hline S20 & & & & ,372 & & \\
\hline S37 & & & & ,365 & & \\
\hline S28 & & & &, 364 & & \\
\hline S9 & & & & & ,686 & \\
\hline S5 & & & & & ,646 & \\
\hline $\mathrm{S} 15$ & & & & &, 518 & \\
\hline $\mathrm{C} 4$ & & & & & & ,807 \\
\hline C14 & & & & & & ,642 \\
\hline $\mathrm{C} 7$ & & & & & & ,546 \\
\hline
\end{tabular}

* Betük: eredetileg melyik skála tétele: S - személyes, T - társas, C - kollektív, K - kapcsolati, X - skálán kívüli 
1. táblázat folyt.

\begin{tabular}{l|c|c|c|c|c}
\hline \multicolumn{7}{c}{ Faktorok közötti korrelációk (Promax) } \\
\hline & F1 & F2 & F3 & F4 & F5 \\
\hline F2 &, 308 & & & & \\
\hline F3 &, 051 &, 156 & & & \\
\hline F4 &, 303 &, 433 &, 103 & & \\
\hline F5 &, 208 &, 262 &,- 175 &, 206 & \\
\hline F6 &, 369 &, 295 &, 218 &, 311 &, 129 \\
\hline
\end{tabular}

2. táblázat. A kérdôív elsố változatának adatain végzett feltáró faktoranalízis eredménye az eredeti skálákhoz viszonyítva

\begin{tabular}{|c|c|c|}
\hline Faktorok & Varimax forgatással & Promax forgatással \\
\hline 1. faktor & a helyidentitásra von. összes tétel & mint Varimax \\
\hline 2. faktor & $\begin{array}{l}\text { a kapcsolati or. tételei } \\
\text {-: K32, K41, } \underline{\mathrm{K} 46} \\
+: \mathrm{S} 12, \mathrm{C} 27\end{array}$ & $\begin{array}{l}\text { mint Varimax } \\
\text { (str. mátrix: K41 korrelál) }\end{array}$ \\
\hline 3. faktor & $\begin{array}{l}\text { társas or. tételei } \\
-: \mathrm{T} 10, \mathrm{~T} 19, \mathrm{~T} 23 \\
+: \varnothing\end{array}$ & mint Varimax \\
\hline 4. faktor & $\begin{array}{l}\text { a személyes or. tételei } \\
\text {-: S2, S5, S9, S12, } \underline{\mathrm{S} 15}, S 28 \\
+: \mathrm{T} 19, \mathrm{~T} 23\end{array}$ & $\begin{array}{l}\text { a személyes or. tételei } \\
\text {-: S2, S5, S9, S12, S15 } \\
\text { +: T19, T23 }\end{array}$ \\
\hline 5. faktor & $\begin{array}{l}\text { a } 4 \text {. faktorból hiányzó } \\
\text { S5, S9, S15 } \\
\text { „elérendô célok” }\end{array}$ & mint Varimax \\
\hline 6. faktor & $\begin{array}{l}\text { a kollektív or. tételei közül a } \\
\text { C4, C7, C14 } \\
\text { „származás” }\end{array}$ & $\begin{array}{l}\text { mint Varimax } \\
\text { (str. mátrix: C33 és C17 } \\
\text { korrelál) }\end{array}$ \\
\hline $\begin{array}{l}\text { Nem került a } \\
\text { fenti faktorokba }\end{array}$ & $\begin{array}{l}\text { S2, T10, C11, S28, K32, C33, K41, C44, } \\
\text { K46, C50 }\end{array}$ & mint Varimax, kivéve S28 \\
\hline
\end{tabular}

Magyarázat: -: hiányzik az eredeti angol nyelvú kérdőív feltüntetett skálájából; +: többlet az eredeti angol nyelvú kérdôív feltüntetett skálájának tételeihez képest; dôlten szedve: faktorba tartozó, de 0,35-nél kisebb faktorsúlyú tétel; aláhúzva: második faktorsúllyal szerepel a faktorban; betúk: eredetileg melyik skála tétele: $\mathrm{S}$ - személyes, T - társas, C - kollektív, K - kapcsolati.

A tételszámok már a helyekre vonatkozó tételek beillesztése következtében módosult új sorszámokat jelentik.

A faktorstruktúra egyik rotációt alkalmazva sem fedte pontosan az eredeti kérdôív skáláit: bizonyos tételek más faktorba kerültek, mint az eredeti angol nyelvú kérdôívben (ilyen a 12., a 19., a 23. és a 27. tétel), mások nem kerültek bele egy faktorba sem (pl. a 2. tétel) vagy különálló faktort alkotnak (pl. a 10., a 32. és a 46. tétel). A kollektív orientáció skálája mutatta a leggyengébb eredményt, hiszen az eredetileg ezen skálába tartozó tételek kis része került egy faktorba, amely tartalma alapján inkább a származás fontosságára utal az identitásban. 
3. táblázat. A kérdôív második változatának adatain végzett feltáró faktoranalízis eredménye az elemzésben értelmezett faktorokat tekintve

\begin{tabular}{|c|c|c|c|c|c|c|c|}
\hline \multicolumn{8}{|c|}{ Varimax forgatással } \\
\hline \multirow[t]{2}{*}{ Tételek* } & \multicolumn{7}{|c|}{ Faktorok } \\
\hline & F1 & $\mathrm{F} 2$ & F3 & $\mathrm{F} 4$ & F5 & F6 & F7 \\
\hline $\mathrm{H} 30$ & ,864 & & & & & & \\
\hline H35 & 816 & & & & & & \\
\hline H21 & ,753 & & & & & & \\
\hline H18 & ,714 & & & & & & \\
\hline H45 & ,705 & & & & & & \\
\hline $\mathrm{H} 40$ & ,704 & & & & & & \\
\hline H8 & 680 & & & & & & \\
\hline $\mathrm{H} 53$ & 673 & & & & & & \\
\hline C14 & 561 & & & & & & \\
\hline $\mathrm{H} 48$ &, 560 & & & & & & \\
\hline K51 & & ,721 & & & & & \\
\hline K49 & & 661 & & & & & \\
\hline K39 & & 630 & & & & & \\
\hline K43 & & 616 & & & & & \\
\hline K36 & & 612 & & & & & \\
\hline K29 & & 601 & & & & & \\
\hline K25 & &, 528 & & & & & \\
\hline K46 & & 489 & & & & &, 435 \\
\hline T13 & & & 840 & & & & \\
\hline T6 & & & 670 & & & & \\
\hline T3 & & &, 594 & & & & \\
\hline T16 & & &, 579 & & & & \\
\hline T19 & & & ,489 & & & & \\
\hline T10 & & & ,408 & & & & \\
\hline $\mathrm{T} 23$ & & & ,357 & & & & \\
\hline \multicolumn{8}{|l|}{$\mathrm{X52}$} \\
\hline S15 & & & & 613 & & & \\
\hline S31 & & & &, 583 & & & \\
\hline S37 & & & & ,570 & & & \\
\hline $\mathrm{S} 20$ & & & &, 550 & & & \\
\hline $\mathrm{S} 24$ & & & & 442 & & & \\
\hline S9 & & & & 431 & & & \\
\hline S5 & & & & 423 & & & \\
\hline \multicolumn{8}{|l|}{$\mathrm{S} 12$} \\
\hline \multicolumn{8}{|l|}{$\mathrm{S} 28$} \\
\hline $\mathrm{C} 50$ & & & & & ,628 & & \\
\hline $\mathrm{C} 33$ & & & & &, 575 & & \\
\hline $\mathrm{C} 44$ & & & & & 487 & & \\
\hline C7 & & & & & ,391 & & \\
\hline
\end{tabular}

\begin{tabular}{|c|c|c|c|c|c|c|c|}
\hline \multicolumn{8}{|c|}{ Promax forgatással } \\
\hline Tételek* & \multicolumn{7}{|c|}{ Faktorok } \\
\hline & $\mathrm{F} 1$ & $\mathrm{~F} 2$ & F3 & $\mathrm{F} 4$ & F5 & F6 & F7 \\
\hline H30 & ,972 & & & & & & \\
\hline H35 & 846 & & & & & & \\
\hline $\mathrm{H} 21$ & 808 & & & & & & \\
\hline $\mathrm{H} 18$ & 806 & & & & & & \\
\hline H8 & ,708 & & & & & & \\
\hline $\mathrm{H} 45$ & 707 & & & & & & \\
\hline $\mathrm{H} 40$ & ,703 & & & & & & \\
\hline $\mathrm{H} 53$ & 644 & & & & & & \\
\hline H48 & ,543 & & & & & & \\
\hline C14 &, 525 & & & & & & \\
\hline K51 & & ,771 & & & & & \\
\hline K49 & & 699 & & & & & \\
\hline K36 & & ,643 & & & & & \\
\hline K39 & & 640 & & & & & \\
\hline K29 & & ,551 & & & & & \\
\hline K43 & &, 542 & & & & & \\
\hline K25 & & ,504 & & & & & \\
\hline T13 & & & 957 & & & & \\
\hline T6 & & & 689 & & & & \\
\hline T3 & & & 631 & & & & \\
\hline T16 & & &, 555 & & & & \\
\hline T19 & & & ,419 & & & & \\
\hline T10 & & & 343 & & & & \\
\hline $\mathrm{S} 15$ & & & & ,660 & & & \\
\hline S37 & & & & ,616 & & & \\
\hline S31 & & & & 601 & & & \\
\hline $\mathrm{S} 20$ & & & &, 575 & & & \\
\hline S24 & & & & ,480 & & & \\
\hline S5 & & & & ,449 & & & \\
\hline \multicolumn{8}{|l|}{$\mathrm{S} 12$} \\
\hline \multicolumn{8}{|l|}{ S28 } \\
\hline C50 & & & & & ,711 & & \\
\hline C33 & & & & &, 557 & & \\
\hline C44 & & & & &, 523 & & \\
\hline \multicolumn{8}{|l|}{$\mathrm{X} 26$} \\
\hline X22 & & & & & & 714 & \\
\hline X54 & & & & & & 680 & \\
\hline \multicolumn{8}{|l|}{$\mathrm{T} 23$} \\
\hline K41 & & & & & & & ,721 \\
\hline
\end{tabular}




\section{3. táblázat folyt.}

\begin{tabular}{l|c|c|c|c|c|c|c|}
\hline \multicolumn{7}{|c|}{ Varimax forgatással } \\
\hline Tételek* & \multicolumn{7}{|c|}{ Faktorok } \\
\hline & F1 & F2 & F3 & F4 & F5 & F6 & F7 \\
\hline X26 & & & & & & & \\
\hline X22 & & & & & &, 635 & \\
\hline X54 & & & & & &, 593 & \\
\hline K41 & &, 397 & & & & &, 662 \\
\hline K32 & & & & & & &, 542 \\
\hline
\end{tabular}

\begin{tabular}{|l|c|c|c|c|c|c|c}
\hline \multicolumn{7}{|c}{ Promax forgatással } \\
\hline Tételek* & \multicolumn{7}{|c}{ Faktorok } \\
\hline & F1 & F2 & F3 & F4 & F5 & F6 & F7 \\
\hline K32 & & & & & & &, 597 \\
\hline K46 & & & & & & &, 425 \\
\hline
\end{tabular}

* Betûk: eredetileg melyik skála tétele: S - személyes, T - társas, C-kollektív, K - kapcsolati, X - skálán kívüli

\begin{tabular}{l|c|c|c|c|c|c}
\hline \multicolumn{7}{c}{ Faktorok közötti korrelációk (Promax) } \\
\hline & F1 & F2 & F3 & F4 & F5 & F6 \\
\hline F2 &, 325 & & & & & \\
\hline F3 &, 161 &, 237 & & & & \\
\hline F4 &, 225 &, 350 &, 078 & & & \\
\hline F5 &, 399 &, 129 &, 296 &, 062 & & \\
\hline F6 &, 181 &, 222 &, 254 &, 234 &, 280 & \\
\hline F7 &, 148 &, 351 &, 070 &, 185 &,- 090 &,- 069 \\
\hline
\end{tabular}

A feltáró analízis eredményei alapján módosított tételeket tartalmazó második változat faktorstruktúráiban több különbség van a ferde és a derékszögú forgatás által létrejött faktortartalmak között, mint az elsô változat esetében.

4. táblázat. A kérdôív második változatának adatain végzett SEM CFA eredménye az elsố 5 faktort tekintve

\begin{tabular}{l|c|c|c|c|c|}
\hline \multicolumn{6}{|c|}{ Promax forgatással } \\
\multicolumn{6}{c|}{ kapott struktúra SEM CFA-eredménye } \\
\hline Tételek* & F1 & F2 & F3 & F4 & F5 \\
\hline H30 &, 867 & & & & \\
\hline H35 &, 855 & & & & \\
\hline H21 &, 775 & & & & \\
\hline H18 &, 685 & & & & \\
\hline H8 &, 667 & & & & \\
\hline H45 &, 680 & & & & \\
\hline H40 &, 728 & & & & \\
\hline H53 &, 654 & & & & \\
\hline H48 &, 577 & & & & \\
\hline C14 &, 570 & & & & \\
\hline K51 & &, 755 & & & \\
\hline K49 & &, 666 & & & \\
\hline
\end{tabular}

\begin{tabular}{|l|c|c|c|c|c}
\hline \multicolumn{6}{|c}{ Varimax forgatással } \\
\hline \multicolumn{1}{|c|}{ kételek* } & F1 & F2 & F3 & F4 & F5 \\
\hline H30 &, 866 & & & & \\
\hline H35 &, 855 & & & & \\
\hline H21 &, 775 & & & & \\
\hline H18 &, 685 & & & & \\
\hline H8 &, 667 & & & & \\
\hline H45 &, 680 & & & & \\
\hline H40 &, 728 & & & & \\
\hline H53 &, 655 & & & & \\
\hline H48 &, 578 & & & & \\
\hline C14 &, 570 & & & & \\
\hline K51 & &, 733 & & & \\
\hline K49 & &, 658 & & & \\
\hline
\end{tabular}




\section{4. táblázat folyt.}

\begin{tabular}{|c|c|c|c|c|c|}
\hline \multicolumn{6}{|c|}{$\begin{array}{l}\text { Promax forgatással } \\
\text { kapott struktúra SEM CFA-eredménye }\end{array}$} \\
\hline Tételek* & F1 & F2 & F3 & F4 & F5 \\
\hline K36 & & ,621 & & & \\
\hline K39 & & ,654 & & & \\
\hline K29 & & ,581 & & & \\
\hline K43 & & ,694 & & & \\
\hline K25 & & ,563 & & & \\
\hline $\mathrm{T} 13$ & & & 850 & & \\
\hline $\mathrm{T} 6$ & & &, 679 & & \\
\hline $\mathrm{T} 3$ & & &, 580 & & \\
\hline T16 & & &, 509 & & \\
\hline T19 & & &, 544 & & \\
\hline $\mathrm{T} 10$ & & & ,335 & & \\
\hline $\mathrm{S} 15$ & & & & , 488 & \\
\hline S37 & & & & ,640 & \\
\hline S31 & & & & ,703 & \\
\hline S20 & & & & ,538 & \\
\hline S24 & & & & ,399 & \\
\hline S5 & & & & ,340 & \\
\hline C50 & & & & & ,705 \\
\hline C33 & & & & & ,699 \\
\hline $\mathrm{C} 44$ & & & & & ,422 \\
\hline & & & & & \\
\hline & & & & & \\
\hline \multicolumn{6}{|c|}{ Faktormeghatározottság } \\
\hline & F1 & F2 & F3 & F4 & F5 \\
\hline & ,961 & ,922 & ,910 & \begin{tabular}{|l|}
, 861 \\
\end{tabular} & ,835 \\
\hline \multicolumn{6}{|l|}{ Korrelációk } \\
\hline & $\mathrm{F} 1$ & $\mathrm{~F} 2$ & F3 & $\mathrm{F} 4$ & \\
\hline $\mathrm{F} 2$ & ,304 & & & & \\
\hline F3 & 050 & 187 & & & \\
\hline $\mathrm{F} 4$ &, 150 & 431 &,- 027 & & \\
\hline F5 & ,331 & ,108 &, 187 &,- 039 & \\
\hline \multicolumn{6}{|c|}{ Hibakovariancia } \\
\hline 53 és 45 & ,337 & & & & \\
\hline 8 és 18 & ,299 & & & & \\
\hline 10 és 16 & ,246 & & & & \\
\hline 5 és 15 & ,206 & & & & \\
\hline
\end{tabular}

\begin{tabular}{|c|c|c|c|c|c|}
\hline \multicolumn{6}{|c|}{$\begin{array}{l}\text { Varimax forgatással } \\
\text { kapott struktúra SEM CFA-eredménye }\end{array}$} \\
\hline Tételek* & F1 & F2 & F3 & $\mathrm{F} 4$ & F5 \\
\hline K36 & & ,631 & & & \\
\hline K39 & & ,647 & & & \\
\hline K29 & & ,586 & & & \\
\hline K43 & & ,714 & & & \\
\hline K25 & &, 556 & & & \\
\hline K46 & & ,632 & & & \\
\hline $\mathrm{T} 13$ & & & 809 & & \\
\hline T6 & & & ,695 & & \\
\hline T3 & & &, 576 & & \\
\hline T16 & & &, 530 & & \\
\hline T19 & & & ,561 & & \\
\hline $\mathrm{T} 10$ & & & ,359 & & \\
\hline $\mathrm{T} 23$ & & & ,409 & & \\
\hline S15 & & & & ,522 & \\
\hline S37 & & & & 636 & \\
\hline S31 & & & & ,669 & \\
\hline $\mathrm{S} 20$ & & & & 542 & \\
\hline $\mathrm{S} 24$ & & & & ,397 & \\
\hline S9 & & & & 435 & \\
\hline S5 & & & & ,384 & \\
\hline $\mathrm{C50}$ & & & & & ,669 \\
\hline C33 & & & & & ,711 \\
\hline C44 & & & & & ,434 \\
\hline $\mathrm{C} 7$ & & & & & ,435 \\
\hline
\end{tabular}

Faktormeghatározottság

\begin{tabular}{|l|c|c|c|c|c}
\hline & F1 & F2 & F3 & F4 & F5 \\
\hline &, 961 &, 929 &, 905 &, 867 &, 844 \\
\hline
\end{tabular}

\section{Korrelációk}

\begin{tabular}{|l|c|c|c|c|}
\hline & F1 & F2 & F3 & F4 \\
\hline F2 &, 319 & & & \\
\hline F3 &, 070 &, 220 & & \\
\hline F4 &, 169 &, 456 &, 009 & \\
\hline F5 &, 354 &, 104 &, 227 &,- 022 \\
\hline
\end{tabular}

\begin{tabular}{|l|r|}
\hline \multicolumn{2}{|l|}{ Hibakovariancia } \\
\hline 53 és 45 &, 337 \\
\hline 8 és 18 &, 298 \\
\hline 10 és 16 &, 227 \\
\hline 5 és 15 &, 171 \\
\hline
\end{tabular}

* Betük: eredetileg melyik skála tétele: $\mathrm{S}$ - személyes, T - társas, C - kollektív, $\mathrm{K}$ - kapcsolati, X - skálán kívüli 
Bár a faktorstruktúra egyik rotációt alkalmazva sem fedte pontosan az eredeti kérdôív skáláit, az elsố változat tételei módosításainak szükségességét az eredmények nagy részben igazolják: a társas orientáció skálája teljesebb lett (Promax rotáció esetében a 23. tétel a mintázat mátrixból hiányzik még, de a struktúra mátrixban szerepel); a személyes skálához tartozó tételek egy faktorba kerültek; a négy eredeti skálát közelítô faktorok egyikébe sem került olyan tétel, amely az eredeti kérdôívben nem szerepelt a skálában; az eredeti skálákhoz képest hiányzó tételek száma kevesebb. A kollektív orientáció skálája bár továbbra is gyenge eredményt mutat (az eredetileg ezen skálába tartozó tételek kis része került egy faktorba), a második változat az eredeti kollektív skálát közelítô 5. faktora már inkább címkézhetô közösségiként (nyelv, nemzeti, politikai, etnikai hovatartozás), azaz a módosítások segítettek az eredeti kollektív tartalom közelítésében. A személyes orientációt mérô skálát tekintve megjegyzendô, hogy a 2. és a 12. tétel az átfogalmazás ellenére sem került be a személyes faktorba, a 28. tétel pedig a kitöltôi visszajelzések alapján tett módosítás után kikerült a személyes faktorból (Promax forgatásnál az elsô változatnál még szerepelt benne).

5. táblázat. A kérdốiv második változatának adatain végzett feltáró faktoranalízis eredménye az eredeti skálákhoz viszonyítva

\begin{tabular}{|c|c|c|}
\hline Faktorok & Varimax forgatással & Promax forgatással \\
\hline 1. faktor & $\begin{array}{l}\text { a helyidentitásra von. összes tétel } \\
+: \text { C14 }\end{array}$ & $\operatorname{mint}$ Varimax \\
\hline 2. faktor & $\begin{array}{l}\text { a kapcsolati or. tételei } \\
\text {-: K32, K41 } \\
+: \varnothing\end{array}$ & $\begin{array}{l}\text { a kapcsolati or. tételei } \\
\text {-: K32, K41, K46 } \\
+: \emptyset\end{array}$ \\
\hline 3. faktor & a társas or. összes tétele & $\begin{array}{l}\text { társas or. tételei } \\
\text {-: T23 } \\
+: \varnothing \\
\text { (str. mátrix: T23 és X52 korrelál) }\end{array}$ \\
\hline 4. faktor & $\begin{array}{l}\text { a személyes or. tételei } \\
\text {-: S2, S12,S28 } \\
+: \varnothing\end{array}$ & $\begin{array}{l}\text { a személyes or. tételei } \\
\text {-: S2, S9, S12, S28 } \\
+: \varnothing \\
\text { (str. mátrix: S9 és S12 korrelál) }\end{array}$ \\
\hline 5. faktor & $\begin{array}{l}\text { a kollektív or. tételei közül a } \\
\text { C7, C33, C44, C50 } \\
\text {-: C4, C11, C14, C27 }\end{array}$ & $\begin{array}{l}\text { a kollektív or. tételei közül a } \\
\text { C33, C44, C50 } \\
\text {-: C4, C7, C11, C14, C27 } \\
\text { (str. mátrix: C7 korrelál) }\end{array}$ \\
\hline 6. faktor & $\begin{array}{l}\text { két skálán kívüli: X22, X54 } \\
\text { „szexualitás” }\end{array}$ & mint Varimax \\
\hline 7. faktor & $\begin{array}{l}\text { a kapcsolati or. tételei közül a } \\
\text { K32, K41 } \\
\text { „partnerrel kapcs. törekvés” }\end{array}$ & $\begin{array}{l}\text { a kapcsolati or. tételei közül a } \\
\text { K32, K41, K46 } \\
\text { „partnerrel kapcs. törekvés” }\end{array}$ \\
\hline $\begin{array}{l}\text { Nem került a } \\
\text { fenti faktorokba }\end{array}$ & $\mathrm{S} 2, \mathrm{C} 4, \mathrm{C} 11, \mathrm{~S} 12, \mathrm{C} 27, \mathrm{~S} 28$ & S2, C4, C7, S9, C11, S12, T23, C27, S28 \\
\hline
\end{tabular}

Magyarázat: -: hiányzik az eredeti angol nyelvú kérdôív feltüntetett skálájából; +: többlet az eredeti angol nyelvú kérdőív feltüntetett skálájának tételeihez képest; dólten szedve: faktorba tartozó, de 0,35-nél kisebb faktorsúlyú tétel; aláhúzva: második faktorsúllyal szerepel a faktorban; betúk: eredetileg melyik skála tétele: S - személyes, T - társas, C - kollektív, K - kapcsolati, X - skálán kívüli.

A tételszámok már a helyekre vonatkozó tételek beillesztése következtében módosult új sorszámokat jelentik. 
A második változat ferde forgatással létrejött faktorstruktúrája a strukturális egyenlet modellezés konfirmatív elemzésének eredménye alapján jó illeszkedést mutat (kevésbé, de szintén jó illeszkedésûnek mondható a Varimax-struktúra is). Ugyanakkor a hibakovarianciák alapján négy pár tétel együttjárást mutat, ezeket a kitöltök hasonlónak értelmezték.

6. táblázat. A kérdőív helyekre vonatkozó tételek nélküli (HN) változatának adatain végzett feltáró faktoranalízis eredménye az elemzésben értelmezett faktorokat tekintve

\begin{tabular}{l|c|c|c|c|c|}
\hline \multicolumn{7}{|c|}{ Varimax forgatással } \\
\hline Tételek* & \multicolumn{5}{|c|}{ Faktorok } \\
\hline & F1 & F2 & F3 & F4 & F5 \\
\hline K43 &, 737 & & & & \\
\hline K46 &, 706 & & & & \\
\hline K32 &, 680 & & & & \\
\hline K29 &, 644 & & & & \\
\hline K25 &, 596 & & & & \\
\hline K39 &, 593 & & & & \\
\hline K49 &, 552 & & & & \\
\hline K51 &, 515 & & & & \\
\hline K36 &, 455 & & & & \\
\hline K41 & & & & & \\
\hline T13 & &, 815 & & & \\
\hline T16 & &, 688 & & & \\
\hline T6 & &, 686 & & & \\
\hline T3 & &, 670 & & & \\
\hline T10 & &, 482 & & & \\
\hline T23 & & & & & \\
\hline S9 & & &, 656 & & \\
\hline S5 & & &, 599 & & \\
\hline S31 & & &, 577 & & \\
\hline S37 & & &, 494 & & \\
\hline S2 & & &, 451 & & \\
\hline S12 & & &, 385 & & \\
\hline C33 & & & &, 684 & \\
\hline C44 & & & &, 549 & \\
\hline C11 & & & &, 356 & \\
\hline X52 & & & & &, 617 \\
\hline X47 & & & & &, 548 \\
\hline C50 & & & & &, 475 \\
\hline X42 & & &, 421 & &, 425 \\
\hline
\end{tabular}

\begin{tabular}{|l|c|c|c|c|c}
\hline \multicolumn{7}{|c}{ Promax forgatással } \\
\hline Tételek* & \multicolumn{5}{|c}{ Faktorok } \\
\hline & F1 & F2 & F3 & F4 & F5 \\
\hline K43 &, 817 & & & & \\
\hline K46 &, 781 & & & & \\
\hline K32 &, 738 & & & & \\
\hline K39 &, 671 & & & & \\
\hline K29 &, 665 & & & & \\
\hline K25 &, 578 & & & & \\
\hline K49 &, 491 & & & & \\
\hline K36 &, 456 & & & & \\
\hline K51 &, 408 & & & & \\
\hline K41 &, 399 & & & & \\
\hline T13 & &, 886 & & & \\
\hline T6 & &, 760 & & & \\
\hline T3 & &, 663 & & & \\
\hline T16 & &, 632 & & & \\
\hline T23 & & & & & \\
\hline S5 & & &, 739 & & \\
\hline S9 & & &, 707 & & \\
\hline S31 & & &, 571 & & \\
\hline S2 & & &, 508 & & \\
\hline S37 & & &, 479 & & \\
\hline X42 & & &, 457 & &, 435 \\
\hline C33 & & & &, 702 & \\
\hline C44 & & & &, 588 & \\
\hline C11 & & & & & \\
\hline X52 & & & & &, 657 \\
\hline X47 & & & & &, 565 \\
\hline C50 & & & & &, 504 \\
\hline
\end{tabular}

* Betûk: eredetileg melyik skála tétele: $\mathrm{S}$ személyes, T - társas, C - kollektív, K - kapcsolati, X - skálán kívüli

\begin{tabular}{|l|c|c|c|c|}
\hline \multicolumn{5}{|c|}{ Faktorok közötti korrelációk (Promax) } \\
\hline & F1 & F2 & F3 & F4 \\
\hline F2 &, 163 & & & \\
\hline F3 &, 578 &, 235 & & \\
\hline F4 &, 224 &, 043 &,- 017 & \\
\hline F5 &, 426 &, 318 &, 356 &, 182 \\
\hline
\end{tabular}


A kérdôív helyidentitásra vonatkozó tételek nélküli (HN) változata az elsố változatban szereplő tételeket tartalmazza, így ezen HN-változat faktoranalízisének eredményeit az elsố változat faktorstruktúrájával összevetve szükséges elemezni. A Promax rotáció eredménye alapján a kapcsolati orientációt közelítô faktorba az eredeti skála minden tétele bekerült a HN-változat esetében (Varimax forgatással egy tétel kimaradt). A társas orientációt tekintve az ezt közelítố faktorból épp azok a tételek maradtak ki a HN-változat esetében, mint az elsố változatnál (ezeket a második változatban átfogalmaztuk). A személyes orientációt közelító faktor a HN-verzió esetében is hiányos, bár a 2. tétel szerepel benne (Varimax rotáció esetében a 12. tétel is). A kollektív orientációt mérô skálát tekintve elmondható, hogy az eredetileg ebbe a skálába tartozó tételeknek csak kis része került egy faktorba a HN-változat esetében is. A magyarázott variancia a kérdôív helyidentitásra vonatkozó tételek nélküli változata esetében is alacsony.

7. táblázat. A kérdôív helyekre vonatkozó tételek nélküli (HN) változatának adatain végzett konfirmatív 4 faktoros analízis eredménye

\begin{tabular}{|l|c|c|c|c|}
\hline \multicolumn{5}{|c|}{ Varimax forgatással } \\
\hline \multicolumn{1}{|c|}{} & \multicolumn{5}{|c|}{ Faktorok } \\
\hline Tételek* & F1 & F2 & F3 & F4 \\
\hline K43 &, 753 & & & \\
\hline K46 &, 684 & & & \\
\hline K49 &, 623 & & & \\
\hline K29 &, 605 &, 351 & & \\
\hline K32 &, 598 & & & \\
\hline K51 &, 582 & & & \\
\hline K39 &, 548 & & & \\
\hline K25 &, 533 &, 404 & & \\
\hline K36 &, 460 & & & \\
\hline C27 & & & & \\
\hline K41 & & & & \\
\hline S20 & & & & \\
\hline S9 & &, 703 & & \\
\hline S31 & &, 587 & & \\
\hline S15 & &, 568 & & \\
\hline S5 & &, 542 & & \\
\hline S37 & &, 535 & & \\
\hline S2 & &, 423 & & \\
\hline X42 & &, 415 & & \\
\hline T19 & &, 389 & & \\
\hline S12 & &, 363 & & \\
\hline T23 & & & & \\
\hline S24 & & & & \\
\hline S28 & & & & \\
\hline T13 & & &, 754 & \\
\hline T16 & & &, 730 & \\
\hline & & & & \\
\hline
\end{tabular}

\begin{tabular}{|l|c|c|c|c|}
\hline \multicolumn{5}{|c|}{ Promax forgatással } \\
\hline \multicolumn{4}{|c|}{} & \multicolumn{5}{|c|}{ Faktorok } \\
\hline Tételek* & F1 & F2 & F3 & F4 \\
\hline K43 &, 828 & & & \\
\hline K46 &, 736 & & & \\
\hline K49 &, 678 & & & \\
\hline K51 &, 586 & & & \\
\hline K29 &, 584 & & & \\
\hline K32 &, 582 & & & \\
\hline K39 &, 577 & & & \\
\hline K25 &, 474 & & & \\
\hline K36 &, 469 & & & \\
\hline C27 & & & & \\
\hline K41 & & & & \\
\hline S20 & & & & \\
\hline S9 & &, 778 & & \\
\hline S15 & &, 607 & & \\
\hline S31 & &, 598 & & \\
\hline S5 & &, 586 & & \\
\hline S37 & &, 564 & & \\
\hline S2 & &, 418 & & \\
\hline X42 & &, 400 & & \\
\hline T19 & &, 366 & & \\
\hline S24 & &, 358 & & \\
\hline S12 & & & & \\
\hline T23 & & & & \\
\hline S28 & & & & \\
\hline T13 & & &, 812 & \\
\hline T16 & & &, 761 & \\
\hline
\end{tabular}




\section{7. táblázat folyt.}

\begin{tabular}{|l|c|c|c|c|}
\hline \multicolumn{5}{|c|}{ Varimax forgatással } \\
\hline \multicolumn{1}{|c|}{} & \multicolumn{3}{|c|}{ Faktorok } \\
\hline Tételek* & F1 & F2 & F3 & F4 \\
\hline T3 & & &, 688 & \\
\hline T6 & & &, 637 & \\
\hline T10 & & &, 543 & \\
\hline X17 & & & & \\
\hline X47 & & & & \\
\hline X1 & & & & \\
\hline C33 & & & &, 579 \\
\hline C7 & & & &, 576 \\
\hline C4 & & & &, 540 \\
\hline C44 & & & &, 446 \\
\hline X38 & & & &, 439 \\
\hline X22 & & & &, 412 \\
\hline C14 & & & &, 411 \\
\hline C11 & & & &, 398 \\
\hline X26 & & & &, 387 \\
\hline X54 & & & &, 359 \\
\hline X34 & & & & \\
\hline C50 & & & & \\
\hline X52 & & & & \\
\hline
\end{tabular}

\begin{tabular}{|l|c|c|c|c|}
\hline \multicolumn{5}{|c|}{ Promax forgatással } \\
\hline & \multicolumn{4}{|c|}{ Faktorok } \\
\hline Tételek* & F1 & F2 & F3 & F4 \\
\hline T3 & & &, 718 & \\
\hline T6 & & &, 686 & \\
\hline T10 & & &, 537 & \\
\hline X17 & & & & \\
\hline X47 & & & & \\
\hline X1 & & & & \\
\hline C33 & & & &, 629 \\
\hline C7 & & & &, 609 \\
\hline C4 & & & &, 590 \\
\hline C44 & & & &, 500 \\
\hline X38 & & & &, 499 \\
\hline C11 & & & &, 434 \\
\hline C14 & & & &, 414 \\
\hline X22 & & & &, 367 \\
\hline X26 & & & &, 350 \\
\hline C50 & & & & \\
\hline X54 & & & & \\
\hline X34 & & & & \\
\hline X52 & & & & \\
\hline
\end{tabular}

* Betük: eredetileg melyik skála tétele: S - személyes, T - társas, C - kollektív, $\mathrm{K}$ - kapcsolati, X - skálán kívüli

\begin{tabular}{|l|c|c|c|}
\hline \multicolumn{4}{|c|}{ Faktorok közötti korrelációk (Promax) } \\
\hline & F1 & F2 & F3 \\
\hline F2 &, 548 & & \\
\hline F3 &, 246 &, 281 & \\
\hline F4 &, 283 &, 295 &, 432 \\
\hline
\end{tabular}


A konfirmatív jellegú analízis 4 faktoros megoldását a feltáró analízis struktúrájával összevetve a Promax forgatás eredményét tekintve a társas orientációhoz tartozó tételek esetén ugyanaz az eredmény született, a kapcsolati orientáció esetében egy tétel kimaradt (Varimax rotációval ez is bekerült), a személyes orientáció tételei ez esetben sem kerültek mind egy faktorba. A magyarázott variancia e négyfaktoros, minden tételt tartalmazó modell esetében is alacsony.

8. táblázat. A kérdôív helyekre vonatkozó tételek nélküli $(\mathrm{HN})$ változatának adatain végzett feltáró és konfirmatív faktoranalízis eredménye az eredeti skálákhoz viszonyítva

\begin{tabular}{|c|c|c|c|c|}
\hline \multirow{2}{*}{ Faktorok } & \multicolumn{2}{|c|}{ Feltáró analízis } & \multicolumn{2}{|c|}{$\begin{array}{c}4 \text { faktoros modell } \\
\text { (konformatív analízis) }\end{array}$} \\
\hline & $\begin{array}{c}\text { Varimax } \\
\text { forgatással }\end{array}$ & $\begin{array}{c}\text { Promax } \\
\text { forgatással }\end{array}$ & $\begin{array}{l}\text { Varimax } \\
\text { forgatással }\end{array}$ & $\begin{array}{c}\text { Promax } \\
\text { forgatással }\end{array}$ \\
\hline 1. faktor & $\begin{array}{l}\text { a kapcsolati or. } \\
\text { tételei } \\
-: \text { K41 } \\
+: \varnothing \\
\end{array}$ & $\begin{array}{l}\text { a kapcsolati orien- } \\
\text { táció összes tétele }\end{array}$ & $\begin{array}{l}\text { a kapcsolati or. } \\
\text { tételei } \\
-: K 41 \\
+: \varnothing\end{array}$ & mint Varimax \\
\hline 2. faktor & $\begin{array}{l}\text { társas or. tételei } \\
\text {-: T19, T23 } \\
\text { +: } \varnothing\end{array}$ & $\begin{array}{l}\text { társas or. tételei } \\
\text {-: T10, T19, T23 } \\
\text { +: Ø } \\
\text { (str. mátrix: T10 } \\
\text { és T23 korrelál) }\end{array}$ & $\begin{array}{l}\text { a személyes or. } \\
\text { tételei } \\
\text {-: S20, S24, S28 } \\
\text { +: T19, X42 }\end{array}$ & $\begin{array}{l}\text { a személyes or. } \\
\text { tételei } \\
\text {-: } S 12, \text { S20, S28 } \\
\text { +: T19, X42 } \\
\text { (str. mátrix: S12 } \\
\text { korrelál) }\end{array}$ \\
\hline 3. faktor & $\begin{array}{l}\text { a személyes or. } \\
\text { tételei } \\
\text {-: } \underline{\mathrm{S} 15}, \mathrm{~S} 20, \mathrm{~S} 24 \text {, } \\
\mathrm{S} 28 \\
+: \varnothing\end{array}$ & $\begin{array}{l}\text { a személyes or. } \\
\text { tételei } \\
\text {-: } \mathrm{S} 12, \underline{\mathrm{S} 15}, \mathrm{~S} 20 \text {, } \\
\mathrm{S} 24, \mathrm{~S} 28 \\
\text { +: X42 } \\
\text { (str. mátrix: S12 } \\
\text { korrelál) }\end{array}$ & $\begin{array}{l}\text { társas or. tételei } \\
-: \text { T19, T23 } \\
+: \varnothing\end{array}$ & mint Varimax \\
\hline 4. faktor & $\begin{array}{l}\text { a kollektív or. téte- } \\
\text { lei közül a } \\
\text { C11, C33, C44 }\end{array}$ & $\operatorname{mint}$ Varimax & $\begin{array}{l}\text { a kollektív or. } \\
\text { tételei } \\
\text {-: C27, C50 } \\
+: \text { X22, X26, X38, } \\
\text { X54 }\end{array}$ & $\begin{array}{l}\text { a kollektív or. } \\
\text { tételei } \\
\text {-: C27, C50 } \\
\text { +: X22, X26, X38 } \\
\text { (str. mátrix: C50 } \\
\text { korrelál) } \\
\end{array}$ \\
\hline 5. faktor & $\begin{array}{l}\text { a kollektív or. téte- } \\
\text { lei közül a C50 } \\
\text { +: X42, X47, X52 }\end{array}$ & $\begin{array}{l}\text { a kollektív or. téte- } \\
\text { lei közül a C50 } \\
\text { +: X47, X52 } \\
\text { (str. mátrix: X42 } \\
\text { korrelál) } \\
\end{array}$ & - & - \\
\hline $\begin{array}{l}\text { Nem került } \\
\text { a fenti fak- } \\
\text { torokba }\end{array}$ & $\begin{array}{l}\text { C4, C7, C14, S15, } \\
\text { T19, S20, T23, } \\
\text { S24, C27, S28, K41 }\end{array}$ & $\begin{array}{l}\text { C4, C7, T10, S12, } \\
\text { C14, S15, T19, } \\
\text { S20, T23, S24, } \\
\text { C27, S28 }\end{array}$ & & \\
\hline
\end{tabular}

Magyarázat: -: hiányzik az eredeti angol nyelvú kérdőív feltüntetett skálájából; +: többlet az eredeti angol nyelvú kérdôív feltüntetett skálájának tételeihez képest; dólten szedve: faktorba tartozó, de 0,35-nél kisebb faktorsúlyú tétel; aláhúzva: második faktorsúllyal szerepel a faktorban; betúk: eredetileg melyik skála tétele: S - személyes, T - társas, C - kollektív, K - kapcsolati, X - skálán kívüli.

A tételszámok már a helyekre vonatkozó tételek beillesztése következtében módosult új sorszámokat jelentik. 
Mindezek alapján elmondható, hogy a HN-változat faktorstruktúrája sem fedi az eredeti kérdốiv faktorszerkezetét, önmagában a helyidentitásra vonatkozó tételek beillesztése nem rontott jelentôsen az eredeti kérdôív faktorstruktúráján.

Összegzésképpen a kérdôív különbözô változatainak feltáró faktoranalízisében kapott eredményeket a 9 . táblázatban foglaltuk össze.

9. táblázat. Az eredeti kérdôív skáláihoz tartozó tételek faktorokban való megjelenése a kérdôív különbözố változataiban feltáró analízis esetén

\begin{tabular}{|c|c|c|c|c|c|c|c|c|}
\hline \multirow[b]{2}{*}{ Skálák } & \multirow{2}{*}{$\begin{array}{l}\text { Angol } \\
\text { nyelvú } \\
\text { eredeti } \\
\text { kérdőív }\end{array}$} & \multirow{2}{*}{$\begin{array}{c}\text { Helyek- } \\
\text { re vo- } \\
\text { natkozó } \\
\text { tételek } \\
\text { beil- } \\
\text { lesztése } \\
\text { utáni új } \\
\text { sorszá- } \\
\text { mokkal } \\
\end{array}$} & \multicolumn{2}{|c|}{$\begin{array}{l}\text { 1. változat faktor- } \\
\text { analízise után }\end{array}$} & \multicolumn{2}{|c|}{$\begin{array}{l}\text { 2. változat faktor- } \\
\text { analízise után }\end{array}$} & \multicolumn{2}{|c|}{$\begin{array}{c}\text { Magyar nyelvú } \\
\text { kérdốív a helyekre } \\
\text { vonatkozó tételek } \\
\text { nélkül }\end{array}$} \\
\hline & & & Varimax & Promax & Varimax & Promax & Varimax & Promax \\
\hline Személyes & $\begin{array}{l}2,5,8, \\
11,14, \\
18,21, \\
25,27, \\
32\end{array}$ & $\begin{array}{l}2,5,9, \\
12,15, \\
20,24, \\
28,31, \\
37\end{array}$ & $\begin{array}{l}\text { F: 4. és } \\
\text { 5. } \\
-: 2,12, \\
28 \\
+: 19,23\end{array}$ & $\begin{array}{l}\text { F: } 4 \text {. és } \\
\text { 5. } \\
\text {-: } 2,12 \\
+: 19,23\end{array}$ & $\begin{array}{l}\mathbf{F}: \mathbf{4} \\
-: 2,12 \\
28 \\
+: \varnothing\end{array}$ & $\begin{array}{l}\text { F: } 4 . \\
-: 2,9 \\
12,28 \\
+: \varnothing\end{array}$ & $\begin{array}{l}\text { F: } 3 . \\
-: 15,20, \\
24,28 \\
+: \varnothing\end{array}$ & $\begin{array}{l}\text { F: } 3 . \\
-: 12, \underline{15}, \\
20,24, \\
28 \\
+: 42\end{array}$ \\
\hline Kapcsolati & $\begin{array}{l}22,26, \\
28,31, \\
34,35 \\
37,39 \\
41,43 \\
\end{array}$ & $\begin{array}{l}25,29, \\
32,36, \\
39,41, \\
43,46, \\
49,51\end{array}$ & \multicolumn{2}{|c|}{$\begin{array}{l}\text { F: } 2 . \\
-: 32,41, \underline{46} \\
+: 12,27\end{array}$} & $\begin{array}{l}\text { F: } 2 . \\
-: 32, \underline{41} \\
+: \varnothing\end{array}$ & $\begin{array}{l}\text { F: } 2 . \\
-: 32 \\
41,46 \\
+: \varnothing\end{array}$ & $\begin{array}{l}\text { F: } 1 . \\
-: 41 \\
+: \varnothing\end{array}$ & $\begin{array}{l}\text { F: } 1 . \\
-: \varnothing \\
+: \varnothing\end{array}$ \\
\hline Társas & $\begin{array}{l}3,6,9 \\
12,15 \\
17,20\end{array}$ & $\begin{array}{l}3,6,10 \\
13,16 \\
19,23\end{array}$ & \multicolumn{2}{|c|}{$\begin{array}{l}\text { F: } 3 . \\
-: \frac{10}{\varnothing}, 19,23 \\
+: \varnothing\end{array}$} & $\begin{array}{l}\text { F: } 3 . \\
-: \varnothing \\
+: \varnothing\end{array}$ & $\begin{array}{l}\text { F: } 3 . \\
-: 23 \\
+: \varnothing\end{array}$ & $\begin{array}{l}\text { F: } 2 . \\
-: 19,23 \\
+: \varnothing\end{array}$ & $\begin{array}{l}\text { F: } 2 . \\
-: 10 \\
19,23 \\
+: \varnothing \\
\end{array}$ \\
\hline Kollektív & $\begin{array}{l}4,7,10 \\
13,24 \\
29,38 \\
42\end{array}$ & $\begin{array}{l}4,7,11 \\
14,27 \\
33,44 \\
50\end{array}$ & \multicolumn{2}{|c|}{$\begin{array}{l}\text { F: } 6 . \\
-: 11,27,33,44, \\
50 \\
+: \varnothing\end{array}$} & $\begin{array}{l}\text { F: } \mathbf{5} . \\
-: 4, \underline{11} \\
14,27 \\
+: \varnothing\end{array}$ & $\begin{array}{l}\mathbf{F}: \mathbf{5} . \\
-: 4,7, \\
11,14, \\
27 \\
+: \varnothing\end{array}$ & \multicolumn{2}{|c|}{$\begin{array}{l}\text { F: } 4 . \\
-: 4,7,14,27,50 \\
+: \varnothing\end{array}$} \\
\hline $\begin{array}{l}\text { Hely- } \\
\text { identitás }\end{array}$ & $\varnothing$ & $\begin{array}{l}8,18, \\
21,30, \\
35,40, \\
45,48, \\
53\end{array}$ & \multicolumn{2}{|l|}{$\begin{array}{l}\text { F: } 1 . \\
-: \varnothing \\
+: \varnothing\end{array}$} & \multicolumn{2}{|l|}{$\begin{array}{l}\text { F: } 1 . \\
-: \varnothing \\
+: 14\end{array}$} & \multicolumn{2}{|l|}{-} \\
\hline
\end{tabular}

Magyarázat: F: faktor sorszáma; -: hiányzik az eredeti angol nyelvú kérdôív feltüntetett skálájából; +: többlet az eredeti angol nyelvú kérdôív feltüntetett skálájának tételeihez képest; dôlten szedve: faktorba tartozó, de 0,35-nél kisebb faktorsúlyú tétel; aláhúzva: második faktorsúllyal ebben a faktorban is szerepel. 


\section{MEGVITATÁS}

Feltételeztük, hogy a helyidentitás vizsgálható és mérhetô identitásorientációként. Mint láttuk, az identitásorientációkat mérô kérdőívbe illesztve a helyidentitásra vonatkozó új tételek egy faktorba rendezôdtek. Az egyes tételek értelmezhetôknek, hasonlóságukkal együtt is megkülönböztethetôknek bizonyultak. Az egyes tételek közötti szignifikáns korrelációs értékek azt igazolják, hogy azok, bár összefüggnek és egy jelenségre vonatkoznak, nem ugyanazon részjelenségeket mérik. A kérdőív második változatában módosított két tétel, amelyek így jobban hangsúlyozzák egy-egy hely személyiséghez kapcsolódását, jobban korrelálnak a többi, nem változtatott tétellel. A faktoranalízis helyekre vonatkozó tételeket tartalmazó faktora érzelmi színezetú, a legnagyobb faktorsúlyú minden struktúra esetében az erôs érzelmi szálakra vonatkozó tétel. A környezettel kapcsolatos érzések és kötődés pedig sok kutató szerint (Proshansky és mtsai, 1983; Korpela, 1989; Lalli, 1992; Droseltis és Vignoles, 2010) szükséges bázisai, részei a helyidentitásnak.

A 9 helyre vonatkozó tételt tartalmazó skálán a kérdőív mindkét változata esetében nagyon változatos összeredmények születtek. Az eredmények alapján elmondható, hogy a vizsgált mintában markáns egyéni különbségek mutatkoztak abban, hogy a személyek számára a helyek és az azokkal kialakított pszichológiai (érzelmi és kognitív) kapcsolat milyen mértékben fontos énfogalmuk meghatározásában, tehát az eredmények igazolják hipotézisünket.

Fontos megjegyezni ugyanakkor, hogy a helyidentitást célzó tételeket tartalmazó faktor minden analízis esetén elsô faktorként szerepel a struktúrában. Elképzelhetô, hogy a magyar nyelven megfogalmazott tételek összetartozása magasabb, mint a lefordított, így bizonyos mértékú jelentésváltozáson átesô tételeké. Az eredmény összefügghet azzal is, hogy a magyarázott variancia már a $\mathrm{HN}$-változat esetében is alacsony (errôl részletesen alább).

Szintén fontos megemlíteni a 14. (az eredeti angol nyelvú kérdôívben 13.) tétel szerepét. A tétel az eredeti angol nyelvú kérdôívben a kollektív skála része volt, a helyek szociális, közösségi vonatkozását célozta. Míg a kérdôív elsố változatában nem került be az általunk készített, helyekre vonatkozó tételek faktorába, a tétel származástartalmát csökkentô módosítása utáni második változatba viszont igen. A kérdôív egy következô, tovább finomított változatában érdemes lehet a tételt úgy átfogalmazni (vagy akár eredeti fordításában megtartani), hogy jobban hangsúlyozza az eredeti kérdôív alkotóinak szándékát, tehát a helyek közösségi vonatkozását.

Feltételeztük azt is, hogy a vizsgálatban használt angol nyelvú kérdôív a tételek lefordítása után az általunk felvett mintán alkalmas az identitásorientációk mérésére. A feltáró faktoranalízis faktorstruktúrája a második változat esetében sem fedi teljesen az eredeti kérdōív skáláit, ám az eltérések három, a személyes, a társas és a kapcsolati orientációt mérố skála esetében nem nagyok, továbbá a második változat faktorstruktúrája, amely a SEM-elemzés alapján jól illeszkedônek tekinthetô, nagyobb átfedést mutat az eredeti angol nyelvú kérdôív skáláival. Ennek megfelelốen hipotézisünket az eredmények részben igazolják.

A ferde és derékszögú forgatással létrejött faktorstruktúrák között igazán nagy különbségeket nem találtunk, ugyanakkor, ha az értékek nem is magasak, a faktorok 
korrelálnak, ami alátámasztja a ferde forgatás használatát. A korrelációs értékekbôl a második változat jelen, az eredeti faktorszerkezetet nem teljesen fedô struktúrája, valamint a kollektív orientációs skála gyenge eredményei alapján jelenleg nehéz volna következtetni a helyidentitásorientáció más orientációkkal való kapcsolatára.

Az eredmények értelmezéséhez mindenképpen szükséges néhány fontos mozzanat említése. Az elsố a vizsgált minta jellemzôi: a kérdôív mindegyik változatát egyetemi hallgatók töltötték ki. Az eredeti teszt (AIQ-IV) negyedik skáláját alkotóik szintén fôiskolás mintán fejlesztették ki (Cheek és mtsai, 2002). Bár az identitás kialakulása szempontjából az egyetemista minta nem jelent hátrányt, Marcia (1987) elméletében az identitásállapotok nyitottak, változékonyak és hajlanak arra, hogy átdolgozzák óket. A tapasztalatok és átélt események alapján a moratórium és az elért identitás egy életen át váltakozik (MAMA-ciklus), az énfogalom bôvül. Feltételezhetốen ennek is köszönhetô, hogy bizonyos tételek a felvett mintán a feltáró analízis szerint esetleges módosításuk ellenére sem az eredeti angol nyelvú kérdôív skáláinak megfelelôen múködtek, így például a partnerrel kapcsolatos törekvés tartalmú három tétel (az egyik, „párom” szót tartalmazó tételnél kitöltéskor többen jelezték, hogy még nem volt párjuk). A személyiség konzisztenciáját közelítő (28.) tétel módosítása (a kitöltés során néhányan jelezték, hogy nem tudják értelmezni a tételt, hiszen ôk érzik a folyamatos változást, ami valószínúsíthetôen összefügg életkorukkal) a faktorba illeszkedés szempontjából tévesnek bizonyult a második változat Promax-struktúrája alapján. Hasonlóképp feltehetốen életkori sajátosságra vezethetô vissza, hogy a második változat feltáró analízisében a 6. faktor egy eredetileg skálákon kívüli két tételt tartalmazó, szexualitás címkével jellemezhetô faktor lett. A kényelmi mintavétel tehát mindenképp korlátozza jelen eredmények általánosíthatóságát.

A második említendô tényezô, hogy - bár a második változat átfogalmazásai közelítették a feltáró analízis faktorstruktúráját az eredeti skálatartalmakhoz, de - bizonyos tételek átfogalmazása a Promax-struktúra mintázat mátrixa alapján nem ért célt. Ilyen az eredetileg a személyes orientáció skálájába tartozó 2. és 12. tétel. E két tétel azért kap nagy hangsúlyt, mert látszatérvényességük szerint egyértelmúen bele kell tartozniuk a személyes orientációs tételek faktorába (a 12. tétel a második változat Promax rotáció struktúra mátrixában szerepel is a személyes orientáció faktorában).

Harmadikként ki kell térnünk a kollektív orientációt mérô skálára, amely tartalmában a legnagyobb eltérés mutatkozott az eredeti és a három magyar nyelvú változat között. Ennek oka valószínúleg elsôsorban a szociokulturális különbségekben rejlik. A hazájára büszke polgár, a politikai tevékenység, az akcentus vagy akár az etnikai háttér, illetve a vallás említése a tételekben, és ezek összefüggései mind jellemzôek az Egyesült Államokra, ahol a kérdôív született. Igaz ez a helyi közösségekre is: a community kifejezés nehezen is fordítható magyarra, és sok esetben erôs vallási és politikai színezete van. A csoporttagság szerepe és értéke ezen fogalmakat tartalmazó tételekkel nem feltétlenül mérhetô jól hazai, egyetemista mintán. Mindezt jól mutatta az elsô változat feltáró faktoranalízisének eredménye. A második változat tételmódosításai a fenti, kulturálisan specifikus megfogalmazások átszövegezését célozták, így az eredeti tételek (közel) fele már egy kollektív jelleggel címkézhetô faktorba került ugyan, de a skála így sem teljes. Érdemes a további vizsgálatokban a magyar viszonyokhoz, társadalmi és kulturális jellemzôkhöz illeszkedô szövegezésú tételekkel megcélozni a 
csoporttagság, a közös értékek identitásban betöltött szerepének felmérését, vagy a helyekre vonatkozó tételekhez hasonlóan részben nem konkrét közösségeket megnevezô tételekkel dolgozni.

Negyedik, de nagyon fontos tényezô, hogy a magyarázott variancia mindegyik változat esetében jócskán elmaradt a társadalomtudományi kutatásokban elvárható értéktôl $(60 \%)$. Minthogy ez ugyanígy igaz a helyekre vonatkozó tételek nélküli változat esetében is, az alacsony varianciát az eredeti kérdôív jellemzôi is okozhatják (az eredeti AIQ-IV kérdőív faktorai által magyarázott varianciát a tanulmányban nem közölték). Mint korábban láttuk, az eredeti kérdôív 45 tételes, ezekből 10 tétel - bár az identitás fontos aspektusaira kérdeznek rá - skálán kívüli. Ezek a tételek mindenképpen ronthatják a magyarázott variancia értékét. A feltáró jellegú analízisben kapott összes, 1-nél magasabb sajátértékú faktor által magyarázott variancia közelíti az 50\%-ot, a második változat esetében pedig, ahol több tétel is a megfelelô faktorba került, a magyarázott variancia értéke valamivel magasabb az elsô változat esetén kapott értékeknél. Mindezek arra engednek következtetni, hogy a magyarázott variancia értéke nem megfelelô faktorba került tételek további pontosításával, illetve az eredeti kérdôívben egyik skálába sem tartozó tételek kihagyásával/csökkentésével javítható volna.

Ezen bevezetố vizsgálat - bár a használt minta miatt korlátozottan általánosítható - eredményei alapján (1) a helyidentitás identitásorientációként történô vizsgálata indokolt: a helyekkel való kapcsolat eltérô fontosságú a különbözó személyek esetében az énfogalom meghatározásában, (2) ez a helyidentitás-orientáció megbízhatóan mérhetô, továbbá (3) a keretül használt kérdôív bizonyos korlátokkal használható az identitásorientációk felmérésére magyar egyetemista mintán is. A jelen kutatás kényelmi mintavételének hatását kiküszöbölve szükségesnek látjuk és elôkészítjük a vizsgálat elvégzését nagy elemszámú, nem egyetemista mintán is a második változat feltáró faktoranalízise során kapott eredmények és a konfirmatív SEM-elemzés hibakovarianciái alapján, valamint a fent említett szociokulturális tényezôk figyelembevételével módosított tételekkel és a skálán kívüli tételek redukálása mellett. A felnôttek mintáján történô felvétel az addigi életévek során szerzett, énfogalomra vonatkozó tapasztalatok hatását tekintve érdekes kutatási eredményeket hozhat. A helyidentitás-orientáció háttere, más identitásoritentációkkal való kapcsolata pedig számos késôbbi vizsgálat alapjául szolgálhat.

\section{IRODALOM}

Bernardo, F., \& Palma-Oliveira, J. (2013). Place Identity, Place Attachment and the Scale of Place: The Impact of Place Salience. Psychology, 4(2), 167-193.

Berzonsky, M. D. (1994). Self-Identity: The Relationship between Process and Content. Journal of Research in Personality, 28(4), 453-460.

Breakwell, G. M. (1986). Coping with Threatened Identity. London: Methuen.

Brown, B., \& Werner, C. (1985). Social Cohesiveness, Territoriality, and Holiday Decorations:

The Influence of cul-de-sacs. Environment and Behavior, 17(5), 539-565.

Buss, A. H. (1980). Éntudatosság és a társas szorongás. In V. Komlósi A., \& Nagy J. (szerk.), (2003). Énelméletek. Személyiség és egészség (pp. 195-216). Budapest: ELTE Eötvös Kiadó.

Canter, D. (1977). The Psychology of Place. London: Architectural Press. 
Casakin, H., Hernández, B., \& Ruiz, C. (2015). Place Attachment and Place Identity in Israeli Cities: The influence of City Size, Cities, 42, 224-230.

Cheek, J. M. (1989). Identity Orientations and Self-Interpretation. In D. M. Buss, \& N. Cantor (Eds), Personality Psychology: Recent Trends and Emerging Directions (pp. 275-285). New York: Springer Verlag.

Cheek, J. M., \& Briggs, S. R. (1982). Self-Consciousness and Aspects of Identity. Journal of Research in Personality, 16(4), 401-408.

Cheek, J. M., Smith, S. M., \& Tropp, L. R. (2002). Relational identity orientation: A fourth scale for the AIQ. Paper presented at the Meeting of the Society for Personality and Social Psychology, Savannah, GA. Letöltve: 2017. 12. 29-én: https://www.researchgate.net/profile/ Jonathan_Cheek/publication/267038939_RELATIONAL_IDENTITY_ORIENTATION_A_ FOURTH_SCALE_FOR_THE_AIQ_Aspects_of_Identity_Questionnaire/links / 544356ec0cf2a76a3ccb1044/RELATIONAL-IDENTITY-ORIENTATION-A-FOURTHSCALE-FOR-THE-AIQ-Aspects-of-Identity-Questionnaire.pdf

Deaux, K. (1993). Reconstructing Social Identity. Personality and Social Psychology Bulletin, 19(1), $4-12$.

Dixon, J., \& Durrheim, K. (2000). Displacing Place-Identity: A Discursive Approach to Locating Self and Other. British Journal of Social Psychology, 39, 27-44.

Droseltis. O., \& Vignoles, V. L. (2010). Towards an Integrative Model of Place Identification: Dimensionality and Predictors of Intrapersonal-Level Place Preferences. Journal of Environmental Psychology, 30(1), 23-34.

Dúll A. (1996). A helyidentitásról. Magyar Pszichológiai Szemle, 36(4-6), 363-391.

Dúll A. (2002). Ember és környezet affektív kapcsolata: a helykötôdés. Alkalmazott Pszichológia, $4(2), 49-65$.

Dúll A. (2009). A környezetpszichológia alapkérdései. Helyek, tárgyak, viselkedés. Budapest: L'Harmattan Kiadó.

Erikson, E. H. (1991). A fiatal Luther és más írások. Budapest: Gondolat Kiadó.

Feldman, R. M. (1990). Settlement-identity: Psychological Bonds with Home Place in a Mobile Society. Environment and Behavior, 22, 183-229.

Félonneau, M.-L. (2004): Love and Loathing of the City: Urbanophilia and Urbanophobia, Topological Identity and Perceived Incivilities. Journal of Environmental Psychology, 24, 43-52.

Fenigstein, A., Scheier, M. F., \& Buss, A. H. (1975). Public and Private Self-Consciousness: Assessment and Theory. Journal of Consulting and Clinical Psychology, 43(4), 522-527.

Greenwald, A. G., \& Pratkanis, A. R. (1984). Az én. In J. László (Ed.), (1992). Válogatás a szociális megismerés szakirodalmából II. (pp. 205-252). Budapest: Tankönyvkiadó.

Hauge, Å. L. (2007). Identity and Place: A Critical Comparison of Three Identity Theories. Architectural Science Review, 50(1), 44-51.

Hernández, B., Hidalgo, M. C., Salazar-Laplace, M. E., \& Hess, S. (2007). Place Attachment and Place Identity in Natives and Non-Natives, Journal of Environmental Psychology, 27, 310-319.

Hinds, J., \& Sparks, P. (2008). Engaging with the Natural Environment: The Role of Affective Connection and Identity. Journal of Environmental Psychology, 28, 109-120.

Hummon, D. M. (1992). Community Attachment: Local sentiment and Sense of Place. In I. Altman, \& S. M. Low (Eds), Place attachment (pp. 253-278). New York: Plenum Press,.

Jorgensen, B. S., \& Stedman, R. C. (2001). Sense of Place as an Attitude: Lakeshore Owners Attitudes Toward Their Properties, Journal of Environmental Psychology, 21, 233-248.

Knez. I., \& Eliasson, I. (2017). Relationships between Personal and Collective Place Identity and Well-Being in Mountain Communities. Frontiers in Psychology, 8, 1-12.

Knez, I. (2014). Place and the Self: An Autobiographical Memory Synthesis, Philosophical Psychology, 27(2), 164-192. 
Korpela, K. M. (1989). Place-Identity as a Product of Environmental Self-regulation. Journal of Environmental Psychology, 9, 241-256.

Kyle, G., Graefe, A., \& Manning, R. (2005). Testing the Dimensionality of Place Attachment in Recreational Settings, Environment and Behavior, 37, 153-177.

Lalli, M. (1992). Urban-Related Identity: Theory, Measurement, and Empirical Findings. Journal of Environmental Psychology, 12, 285-303.

Main, K., \& Sandoval, G. F. (2015). Placemaking in a Translocal Receiving Community: The Relevance of Place to Identity and Agency, Urban Studies, 52(1), 71-86.

Manzo, L. C. (2003). Beyond House and Haven: toward a Revisioning of Emotional Relationships with Places. Journal of Environmental Psychology, 23, 47-61.

Marcia, J. E. (1966). Development and Validation of Ego Identity Status. Journal of Personality and Social Psychology, 3(5), 551-558.

Marcia, J. E. (1987). The Identity Status Approach to the Study of Ego Identity Development. In T. Honess, \& K. Yardley (Eds), Self and Identity: Perspectives across the Lifespan (pp. 87-92). New York: Routledge.

MacCallum, R. C., Widaman, K. F., Zhang, S., \& Hong, S. (1999). Sample Size in Factor Analysis. Psychological Methods, 4, 84-99.

Neisser, U. (1988). Az önmagunkról való tudás öt válfaja. In J. László (Ed.), (1992). Válogatás a szociális megismerés szakirodalmából II. (pp. 173-204). Budapest: Tankönyvkiadó.

Oyserman, D., Elmore, K., \& Smith, G. (2012). Self, Self-Concept, and Identity. In M. R. Leary, \& J. P. Tangney (Eds), Handbook of Self and Identity (pp. 69-104). New York: The Guilford Press.

Proshansky, H. M. (1978). The City and Self-Identity. Environment and Behavior, 10(2), 147169.

Proshansky, H. M., Fabian, A. K., \& Kaminoff, R. (1983). Place-Identity: Physical World Socialization of the Self. Journal of Environmental Psychology, 3, 57-83.

Rollero, C., \& De Piccoli, N. (2010). Place Attachment, Identification and Environment Perception: An Empirical Study, Journal of Environmental Psychology, 30, 198-205.

Sampson, E. E. (1978). Personality and the Location of Identity. Journal of Personality, 46(3), 552-568.

Sedikides, C., \& Brewer, M. B. (2001). Individual Self, Rational Self, and Collective Self. Partners, Opponents, or Strangers? In C. Sedikides, \& M. B. Brewer (Eds), Individual Self, Relational Self, Collective Self (pp. 1-6). Philadelphia: Psychology Press.

Snyder, M. (1979). Önmonitorozási folyamatok. In V. Komlósi A., \& Nagy J. (szerk.), (2003). Énelméletek. Személyiség és egészség (pp. 217-254). Budapest: ELTE Eötvös Kiadó.

Stokols, D., \& Shumaker, S. A. (1981). People in Places: A Transactional View of Settings. In Harvey, J. H. (Ed.), Cognition, Social Behavior, and the Environment (pp. 441-489). Hillsdale: Lawrence Erlbaum,

Tajfel, H. (1982). Social Psychology of Intergroup Relations. Annual Review of Psychology, 33, $1-39$.

Turner, J. C., \& Reynolds, K. J. (2012). Self-Categorization Theory. In P. A. M. van Lange, A. W., Kruglanski, \& E. T. Higgins (Eds), Handbook of Theories of Social Psychology (vol. 2., pp. 399417). London: Sage.

Twigger-Ross, C. L., \& Uzzell, D. L. (1996). Place and Identity Processes. Journal of Environmental Psychology, 16, 205-220.

Twigger-Ross, C. L., Bonaiuto, M., \& Breakwell, G. (2003). Identity Theories and Environmental Psychology. In M. Bonnes, T. Lee, \& M. Bonaiuto (Eds), Psychological Theories for Environmental Issues (pp. 203-233). Aldershot: Ashgate. 
Uzzell, D. L., Pol, E., \& Badenas, D. (2002). Place Identification, Social Cohesion, and Environmental Sustainability. Environment and Behavior, 34(1), 26-53.

Williams, D. R., \& Roggenbuck, J. W. (1989). Measuring Place Attachment: Some Preliminary Results. In: L. H. McAvoy, \& D. Howard (Eds) Abstracts of the 1989 Leisure Research Symposium (p. 32). Arlington, VA: National Recreation and Park Association.

http://academics.wellesley.edu/Psychology/Cheek/identity.html (utolsó látogatás: 2018. 02. 25.)

\title{
PLACE IDENTITY AS IDENTITY ORIENTATION?
}

\author{
BERZE, IVÁN ZSOLT - DÚLL, ANDREA
}

The primary aim of our study, as a new approach, was to relate the theory of place identity to concepts of identity orientations. We hypothesized that place identity can be measured as identity orientation, so we can find meaningful and reliably measurable individual differences in the extent to which the relationship with places is important for the individuals to their sense of who they are. We also hypothesized that the translated, into Hungarian, version of the questionnaire (AIQ-IV, Cheek, Smith, E Tropp, 2002) effectively measures identity orientations on the sample of this study. Methods: We used the translated version of AIQ-IV, in which we inserted the items relating to place identity formulated on the basis of the literature. We tested three versions of the questionnaire on university student samples $(n=318,317,281)$, and we conducted factor analysis in all three cases. We developed the second version after the revision of the first version based on the results. The first version was completed without the place-related items to investigate whether these items changed the integrity of the original questionnaire. Results: All of the place-related items were included in a single factor, the results of the statistical analysis of this scale were found to be ideal, the participants could interpret place-related items for the definition of themselves. The scores of participants on this scale were normally distributed. However, the factor structure of the second version of the questionnaire did not exactly fit to the scale structure of the original questionnaire. Discussion: The results contribute to a more subtle interpretation of the concept of place identity. Our future aim is to develop a modified version based on the results and to test it a large non-student sample.

Keywords: place identity, (self-)identity, self-concept, identity orientation 